\title{
28. STUDENT IM VOLK: „TKO NIJE S NAMA, TAJ JE PROTIV NAS!”
}

\section{Ivana Cvijović Javorina}

UDK: 050(497.5=112.2)-057.87“1939“

Izvorni znanstveni članak

Sažetak: U ožujku 1939. objavljen je prvi broj tromjesečnika Student im Volk, glasila Udruženja njemačkih studenata u Zagrebu, namijenjenog svim studentima njemačke narodnosti u Jugoslaviji. Pored tekstova o uobičajenim studentskim temama, velik dio njegova sadržaja činili su tekstovi normativne naravi, u kojima su se studentima davale aktualne smjernice kako doprinijeti ostvarenju zamišljenog ideala njemačke narodne zajednice, to jest kako postati njezin aktivan član $s$ razvijenom sviješću o vlastitim dužnostima. Dužnost pojedinca prema narodu stavljena je na prvo mjesto: njemačkim studentima više nisu smjeli biti važni osobni interesi, nego službeno proklamirana ideologija krvi, tla i časti. Vlasti su odmah počele pratiti pisanje glasila, a pojačale su i nadzor nad članovima Udruženja zbog sumnje u širenje nacističkih ideja. Posebna pozornost posvećivala se aktivnostima Landesstudentenführera Willija Badla, vlasnika lista, i Richarda Stieba, glavnog urednika. U radu se analiziraju tekstovi iz navedenog glasila i propituje njegova uloga u procesu etničko-ideološke mobilizacije studenata. Pokušava se odgovoriti na pitanje koje je sve intelektualne, profesionalne i moralne osobine, prema listu Student im Volk, trebao imati njemački student. Na kraju analize sažima se shvaćanje pojma „intelektualac” koje je Student im Volk promicao 1939. i 1940. godine.*

Ključne riječi: studenti, nacizam, Nijemci u Jugoslaviji, intelektualci, inteligencija, Udruženje njemačkih studenata u Zagrebu, mobilizacija, Student im Volk, Willi Badl

\section{Njemačka studentska udruženja u službi narodnoj zajednici}

(1)

rujnu 1939. godine Willi Badl, od 1938. do 1941. Landesstudentenführer, to jest vođa njemačkih studenata u Jugoslaviji, i vlasnik njihovog glasila Student im Volk, piše:

Naposljetku, kao studentska udruženja (studentische Kameradschaften) mi danas više nismo članovi uskih drugarskih krugova (Kameradschaftskreise), nego se osjećamo kao članovi naše velike njemačke narodne zajednice. Naša udruženja ne smiju biti intelektualni kružoci,

\footnotetext{
Srdačno zahvaljujem prof. dr. sc. Damiru Borasu na računalnoj obradi tekstova objavljenih u glasilu Student im Volk.
} 
nego mjesta odgoja u kojima će svi drugovi (Kameraden) biti svjesni da je njihova prva i najviša dužnost služba u narodnoj zajednici (Volksgemeinschaft). ${ }^{1}$

I dok su njemački studenti u Zagrebu koju godinu ranije - prema riječima jednoga od njih - s nestrpljenjem očekivali nedjelju i blagdan kako bi se „isključili” od tjednih radnih obveza i uputili na opuštajuću šetnju Sljemenom, Remetama, Šestinama ili Medvedgradom ili kako bi pak „s knjigom u ruci uređenim šumskim stazama ili asfaltnom cestom obrubljenom vrtovima okolnih vila" ${ }^{2}$ krenuli prema Cmroku, krajem tridesetih godina mnogo se toga promijenilo u njihovim životima. „Bezazlene vedre šetnje po okolici Zagreba”, sastanke „pod repom’ brončanog konja na Jelačić placu”, Jelačićevu sablju, koja im je pokazivala smjer prema baru koji su posjećivali kad su bili „bez djevojaka a pri kasi”, česte odlaske u Gradsku kavanu „u svako doba dana i noći” te ostajanje u „Lovačkom rogu, ili kojoj drugoj pivnici - dok ne bi bili mrtvi od piva" ili dok posjeti noćnim lokalima ne bi završili „platežnom nesposobnošću sudionika” ${ }^{3}$ - zamijenio je novi oblik „druženja”. Umjesto da bezbrižno provode svoje slobodno vrijeme u prijateljskim krugovima, od njemačkih se studenata počelo očekivati da slobodno vrijeme koriste isključivo za poboljšanje životnih uvjeta i napredak čitave narodne zajednice. ${ }^{4}$

U citiranom članku Badl je naglasio još jednu važnu novinu u poimanju studentskog života. Odbacujući bilo kakav oblik izdvajanja iz zajednice na temelju društvenog statusa, jasno je dao do znanja da „pravi” njemački studenti i (budući) akademski obrazovani građani neće imati nikakav povlašten položaj u društvu samo zato što pripadaju malobrojnoj skupini onih koji su u to vrijeme imali mogućnost stjecanja fakultetskog obrazovanja. Stvaranje bilo kakvih „intelektualnih kružoka” bilo je ne samo nepoželjno, nego i nedopustivo. Istaknuto mjesto u društvu moglo im je pripasti samo pod uvjetom da ispunjavaju svoje dužnosti prema narodnoj zajednici.

Nemoguće je ne uočiti Badlov implicitni prijezir prema „intelektualizmu”. Krene li se od uobičajenog shvaćanja prema kojem se intelektualcima smatra osobe koje imaju visokoškolsko obrazovanje, znanstvenog ili umjetničkog usmjerenja, te se u konačnici bave umnim radom, ${ }^{5}$ može se zaključiti da su studenti u osnovi imali predispozicije postati ,intelektualci”. No pravo je pitanje jesu li oni, prema mišljenju ljudi poput Badla, smjeli biti ,intelektualci”. Ne ulazeći u to kakvu ulogu mogu imati akademski obrazovani građani u artikuliranju političkih zahtjeva te u formiranju javnog mišljenja i obrazaca percepcije društtvene zbilje u moderno doba, neosporno je da njihova "praktična” znanja itekako doprinose zajednici u kojoj žive. Nije teško zamisliti koliku je važnost imala prisutnost liječnika u nekom zabače-

Willi BADL, „Die Grundlinien unserer Arbeit”, Student im Volk, 1/1939., br. 3, 1.-3. Ovdje 2. Citate iz Student im Volk i ostalih publikacija objavljenih na njemačkom jeziku prevela I.C.J.

2 Josef MÜLLER, „O djelovanju njemačkih visokoškolaca u Zagrebu (Sjećanje na osnutak VDH - Zagreb i Suevia Beograd)", Povijesne zaobilaznice: Nijemci i Austrijanci u Hrvatskoj, (ur. Nives Rittig Beljak i Ljiljana Marks), Zagreb 2009., 199.-211. Ovdje 201.

Isto, 206.

4 Ideja o mladeži koja doprinosi razvoju svoje narodne zajednice nije nipošto bila novost nastala u vrijeme nacionalsocijalizma. Tako se, primjerice, 1919. godine od njemačkih studenata tražilo da čuvaju čistoću njemačkog jezika, njeguju njemačke običaje i čine sve ono što Njemačku čini velikom i jakom, njemački narod časnim i vrijednim poštovanja, a njemačko ime slavnim. Istaknuto je da je dužnost svakog „pobožnog i časnog” njemačkog muškarca ili mladića da iz njemačkog života i jezika izbacuje sve ono što je strano i nije u domovinskom duhu. Međutim, tijekom nacističke vladavine nije više bilo riječi samo o očuvanju vlastite tradicije, nego je glavni cilj postalo prvenstvo interesa njemačke moći, kulture i politike spram drugih nacija. Friedrich ZUNKEL, „Ehre, Reputation”, Geschichtliche Grundbegriffe, sv. 2, Stuttgart 1992., 1.-63. Ovdje 58.

5 Duden. Deutsches Universalwörterbuch, Mannheim - Leipzig - Wien - Zürich 2003., 839.; Vladimir ANIĆ, Rječnik brvatskoga jezika, Zagreb 2000., 317. 

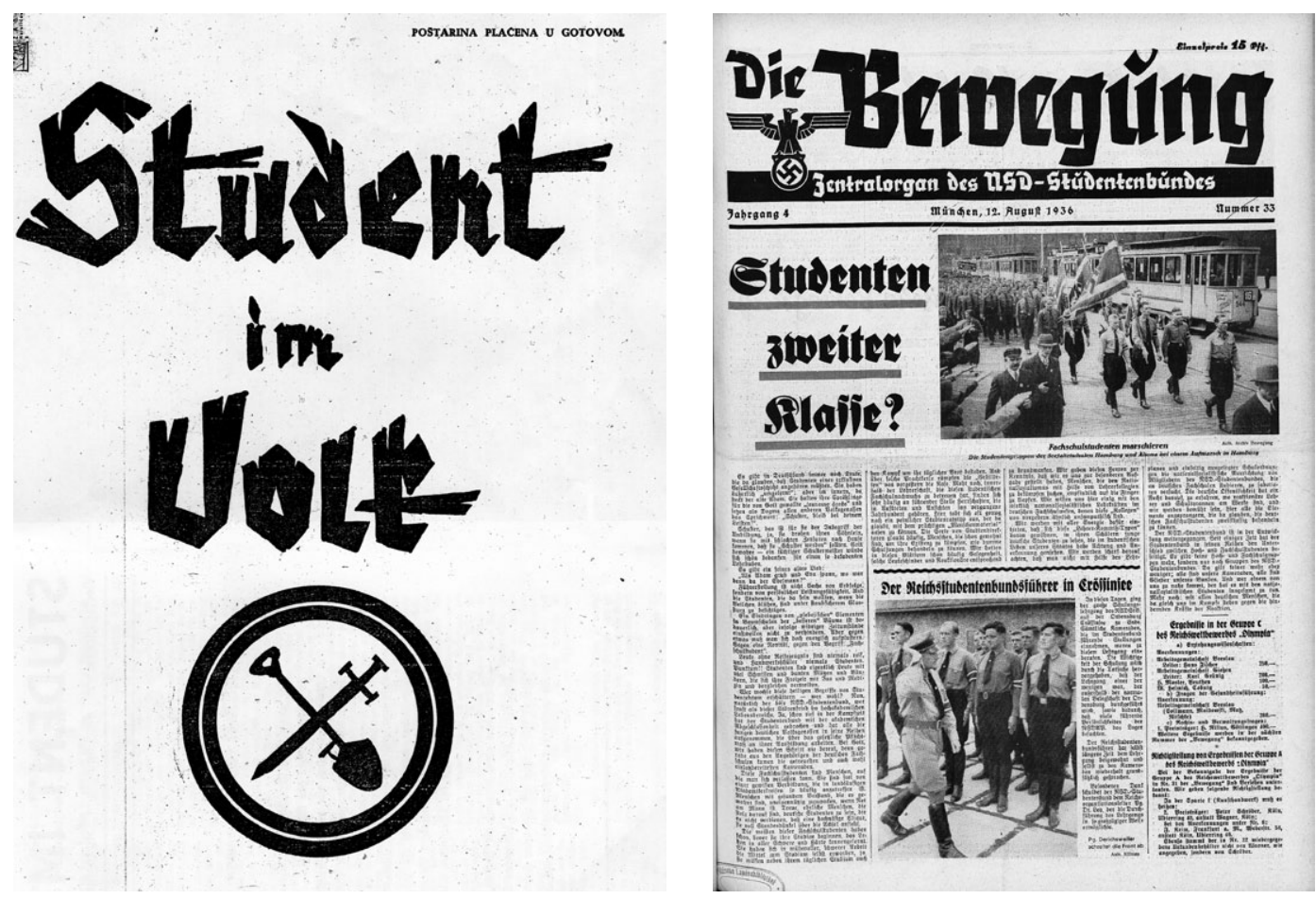

Slika 1. Naslovnica glasila Student im Volk

Slika 2. Naslovnica glasila Die Bewegung

nom selu, odvjetnika spremnog pomoći „običnim ljudima” u sporovima oko nasljedstva ili učitelja koji je djecu učio čitati, pisati i računati. Njihova je važnost bila još i veća ako se uzme u obzir da je u to doba udio fakultetski obrazovanih ljudi bio iznimno nizak. ${ }^{6}$ Bilo bi, dakle, potpuno suludo pomisliti da je Badl, koji je i sam bio student, u svom „antiintelektualizmu” bio protiv visokog obrazovanja. Naprotiv, fakultetsko je obrazovanje i u „novom poretku” bilo na visokoj cijeni, ali ipak - ono nije smjelo proizvoditi ,intelektualce”!

Iz ovih nekoliko uvodnih napomena vidljivo je da se između fakultetski obrazovanih osoba i „intelektualaca” nije smio stavljati znak jednakosti. Stoga se nameće nekoliko pitanja: Budući da je u tadašnjem diskursu očito postojao, koje je značajke sadržavao pojam „intelektualac” i na koga se odnosio? Ako se na temelju navedenoga pođe od pretpostavke da je ,intelektualac” bio pojam s negativnim konotacijama, neizbježno je zapitati se je li bila ponuđena primjerena alternativa tom pojmu i što je ona sve obuhvaćala.

Odgovor na ta pitanja leži, između ostaloga, i u tekstovima objavljenima u Student im Volk. Dijelom su ih pisali članovi Udruženja njemačkih studenata u Zagrebu ili studenti njemačke narodnosti s raznih strana Kraljevine Jugoslavije i susjednih zemalja, a dijelom potječu iz različitih glasila - ne samo studentskih - tiskanih u Trećem Reichu, primjerice iz službenog glasila njemačkih studenata u Reichu, Die Bewegung. Usporedi li se Student im Volk s Die Bewegung, list tiskan u Zagrebu djeluje - u najmanju ruku - vrlo skromno. U njemu nema fotografija, nema oglasa ni reklama i premda bi se letimičnim pregledom

\footnotetext{
Udio visokoobrazovanih osoba među Nijemcima iznosio je svega dva posto. (Branko PETRANOVIĆ, Istorija Jugoslavije 1918 - 1988. Knjiga prva, Beograd 1980., 58.; Vladimir GEIGER, „Njemačka manjina u Kraljevini Srba, Hrvata i Slovenaca / Jugoslaviji (1918. - 1941.)”, Dijalog povjesničara - istoričara, 2, (ur. Hans-Georg Fleck i Igor Graovac), Zagreb 2000., 429.-445. Ovdje 440.)
} 
njegova sadržaja moglo pogrešno zaključiti da se radi o nasumično „nabacanim” tekstovima, koji baš i nemaju previše veze jedan s drugim, već $\mathrm{i}$ usporedbom naslova tekstova $u$ oba časopisa lako se mogu uočiti vrlo velike tematske sličnosti, uz već spomenuto izravno preuzimanje tekstova iz njemačkog lista. ${ }^{7}$

U Student im Volk nema izravnih poziva studentima za uskraćivanje lojalnosti državi u kojoj žive odnosno poticanja na protudržavno djelovanje. Međutim, način na koji se raspravlja o statusu i zadaćama njemačke manjine u Kraljevini Jugoslaviji te kako se inače vrijednosno i praktično usmjerava čitatelje tog glasila svjedoči o utjecajima nacionalsocijalizma i „buđenju” sunarodnjaka odnosno njihovoj političkoj, a nakon 1. rujna 1939. godine i ratnoj mobilizaciji.

Stoga se nameće još jedno pitanje: u kojoj je mjeri taj naizgled skromni časopis od svega šesnaest stranica tiskanih na „,njemačkom pismu” (deutsche Schrift) uopće mogao biti iskorišten u procesu mobilizacije? Kao interpretacijski okvir može poslužiti koncept etničke mobilizacije Miltona J. Esmana, koji pod tim pojmom podrazumijeva proces u kojemu etnička zajednica postaje politizirana u ime svojih kolektivnih interesa i težnji. Esman etničkom zajednicom smatra grupu ljudi ujedinjenih naslijeđenom kulturom, rasnim karakteristikama, sustavom vjerovanja (religijom) ili nacionalnim osjećajima. ${ }^{8}$ Taj proces zahtijeva svijest - koju obično promiču ethnic entrepreneurs - da je politička akcija potrebna za promociju ili obranu vitalnih kolektivnih interesa zajednice. Ta svijest pak rezultira uključivanjem pojedinaca u pokret ili specifičnu organizaciju koja nastoji govoriti u ime pokreta. ${ }^{9}$ Prema Esmanu, proces etničke mobilizacije ne mora biti obilježen samo iskustvom relativne deprivacije, nego i „očekivanjima”. ${ }^{10} \mathrm{Na}$ proces mobilizacije pritom utječe sedam uzajamno ovisnih varijabli: politički kontekst (opportunity structure), vodstvo (leadership), ideologija (ideology), organizacija (organization), resursi (resources), ciljevi (goals) te strategije i taktike (strategies/tactics). ${ }^{11}$

Ovaj uopćeni koncept može se primijeniti i na slučaj mobilizacije njemačke manjine u Kraljevini Jugoslaviji, ali pritom treba upozoriti na nekoliko važnih specifičnosti. Naime, nije svejedno živi li skupina koju treba mobilizirati na teritoriju omeđenom državnim granicama ili izvan njih. U ovom konkretnom slučaju bitno je imati na umu da je nacifikacija Nijemaca u Jugoslaviji bila dirigirana iz Trećeg Reicha, ali i da su se politički konteksti u pojedinim zemljama Kraljevine Jugoslavije, kada je o Nijemcima riječ, uvelike razlikovali. ${ }^{12}$

Usp. Dr. Franz RONNEBERGER, „Unsere studentische Aussenarbeit”, Student im Volk, 1/1939., br. 3, 5.-6. i Dr. Gustav Adolf SCHEEL, „Die Aufgabe und Durchführung der studentischen Dienstpflicht”, Student im Volk, 2/1940., br. 1, 14.-15.

Milton J. ESMAN, Ethnic politics, New York 1994., 26.

9 M. J. ESMAN, Ethnic politics, 28. Usp. i Carl BETHKE, Deutsche und ungarische Minderheiten in Kroatien und der Vojvodina 1918-1941. Identitätsentwürfe und ethnopolitische Mobilisierung, Wiesbaden 2009., 29.

10 C. BETHKE, Deutsche und ungarische Minderheiten in Kroatien und der Vojvodina 1918-1941., 29.

11 M. J. ESMAN, Ethnic politics, 28. Usp. i C. BETHKE, Deutsche und ungarische Minderheiten in Kroatien und der Vojvodina 1918-1941., 28.-32.

12 Usp. o položaju Nijemaca u Hrvatskoj: Vladimir GEIGER, „Položaj njemačke manjine u bivšoj Jugoslaviji (s posebnim osvrtom na razdoblje nakon drugog svjetskog rata)”, Historijski zbornik, 46/1993., br. 1, 165.-175.; ISTI, „Njemačka manjina u Kraljevini Srba, Hrvata i Slovenaca / Jugoslaviji (1918. - 1941.)"; ISTI, Nijemci u Đakovu i Đakovštini, Zagreb 2001.; ISTI, Nijemci Đakova i Đakovštine od 1848. do 1914. godine, sv. 1 i sv. 2, Zagreb 2001. i 2002.; Goran BEUS RICHEMBERGH, Nijemci, Austrijanci i Hrvati I. Prilozi za povijest njemačko-austrijske nacionalne manjine u Hrvatskoj i Bosni i Hercegovini, Zagreb - Sarajevo - Osijek 2010. Položaj Nijemaca u Srbiji opisan je u: Zoran JANJETOVIĆ, Deca careva, pastorčad kraljeva. Nacionalne manjine u Jugoslaviji 1918-1941, Beograd 2005.; ISTI, Nemci u Vojvodini, Beograd 2009. O položaju Nijemaca u Sloveniji: Mitja FERENC - Božo REPE, „Nemška manjšina v Sloveniji med obema vojnama”, Slovensko-avstrijski odnosi v 20 stoletju. Slowenisch - österreichische 
Politički konteksti su imali i svoje socio-statusne aspekte. Nije svejedno radi li se o političkoj mobilizaciji siromašnoga, uglavnom nepismenog seljaštva ili studentske populacije.

Iako je nemoguće u ovom radu detaljno propitati i u jednakoj mjeri analizirati sve navedene čimbenike, analizom članaka iz Student im Volk može se dobiti uvid u društvene i narodnosne vrijednosti i prakse koje je to glasilo posredovalo, a time i pokušati dati odgovor na pitanje o njegovoj ulozi u procesu političke mobilizacije njemačkih studenata u Jugoslaviji neposredno uoči i nakon početka Drugoga svjetskog rata.

\section{Student im Volk - glasilo „obnovljenog” Udruženja njemačkih studenata u Zagrebu}

Prvi broj glasila Student im Volk. Vierteljahresschrift der deutschen Studentenschaft in Jugoslawien (Student u narodu. Tromjesečnik njemačkih studenta u Jugoslaviji) objavljen je 1. ožujka 1939. godine i izašlo je svega nekoliko brojeva. ${ }^{13}$ Početkom ožujka 1940 . godine Ministarstvo unutrašnjih poslova naredilo je vlastima Banovine Hrvatske da ,izvol(e) skrenuti pažnju Državnom tužiocu na pisanje mjesečnika (sic!) 'Student im Volk', koji i već u svome prvom broju prelazi stroge granice lojalnosti i zakona." 14

O tom „tiskopisu” Uprava policije u Zagrebu poslala je podatke Odjeljku za državnu zaštitu Kraljevske banske uprave Savske banovine. Kao glavni i odgovorni urednik spominje se Richard Stieb, rođen 16. studenoga 1916. u Tordincima, student medicine u Zagrebu. U pogledu pravca pisanja, vlasti su ovo studentsko glasilo označile kao „kulturno-politički list nemačkih studenata nacionalističkog karaktera”. ${ }^{15}$ Predviđena učestalost izlaženja lista bila je svaka tri mjeseca, a trebao se tiskati u tisuću primjeraka. U spomenutom policijskom izvještaju navodi se da je vlasnik Wilhelm Badl, ${ }^{16}$ rođen 22. rujna $1917 .{ }^{17}$ u Innsbrucku te da list nema stalnih suradnika, već „neodređen broj dopisnika”, uglavnom članova Udruženja njemačkih studenata u Zagrebu. ${ }^{18}$ Prvi broj lista je izgleda odmah bio razgrabljen, a prema riječima Willija Badla, pohvale su stizale od Nijemaca čak od Danske do Rumunjske. ${ }^{19}$

Beziehungen im 20. Jahrhundert, (ur. Dušan Nećak i dr.), Ljubljana 2004., 147.-160. Usp. i članak u ovom zborniku: Božo REPE, „Intelektualci, političke stranke i grupacije u Sloveniji u predvečerje Drugog svetskog rata”.

13 U Hrvatskom državnom arhivu u Zagrebu (dalje: HDA), u Zbirci špijunaža i peta kolona, čuvaju se tri primjerka Student im Volk: 2. i 3. broj 1. godišta (lipanj i rujan 1939.) te 1. broj 2. godišta (ožujak 1940.). Prvi broj prvog godišta nije sačuvan. U digitaliziranom katalogu Leksikografskog zavoda Miroslav Krleža (http://katalog.lzmk.hr/autorski.aspx?box=Kutija_A748) spominju se i tekstovi objavljeni u 2. broju 2. godišta, npr. pjesme F. Tella, „Ihr baut die Dome” i „Empor”, što znači da je sasvim sigurno objavljeno barem pet brojeva ovog glasila.

14 HDA 1358: grupa XI, kut. 29, inv. br. 2776.

15 Isto.

16 U tekstovima objavljenim u glasilu Student im Volk, novinama Deutsche Nachrichten, kao i u obavijesti o Badlovoj smrti objavljenoj u novinama Marburger Zeitung od 16. ožujka 1943. te u nekrologu objavljenom u glasilu Die Bewegung s kraja veljače 1944. uz Badlovo prezime javlja se jedino varijanta imena Willi.

17 U zapisniku Redarstvenog ravnateljstva u Zagrebu od 29. 11. 1939. piše da je Badl rođen u mjesecu studenome. Očito je u jednom slučaju došlo do pogreške pri upisu mjeseca rimskim brojem IX. odnosno XI. (HDA 1358: grupa XI, kut. 29, inv. br. 2776.)

18 Prema sačuvanom dokumentu, Student im Volk se tiskao u tiskari „Slovo” u Radišinoj ulici, vlasnika Mihajla Zagote (HDA 1358: grupa XI, kut. 29, inv. br. 2776), ali na sačuvanim primjercima navedena je tiskara Julija Kurzmanna iz Dalmatinske ulice. U njoj su se tiskale i novine Deutsche Nachrichten.

19 Willi BADL, „Rückschau und Ausblick - Ein Arbeitsjahr”, Student im Volk, 1/1939., br. 2, 8.-10. Ovdje 10. 
Tridesetih godina dvadesetog stoljeća postojalo je nekoliko udruženja njemačkih studenata u Jugoslaviji, a jedno od njih bilo je i spomenuto Udruženje njemačkih studenata u Zagrebu (Vereinigung deutscher Hochschüler in Zagreb - VDH). ${ }^{20}$ Udruženje je osnovano 1925. godine, ali su društvena pravila odobrena tek 1931./1932. Prema pravilima,

„(s)vrha udruženja jest:

1. Zajednički studiski rad,

2. Negovanje druževnosti i prosvete medju članovima

3. Udruženje se ne bavi politikom."21

O nedovoljnoj istraženosti ove teme svjedoči i neslaganje oko godine osnutka pa se kao početak rada navode još i $1926 .{ }^{22}$ i 1928 . godina. ${ }^{23}$ Josef Müller u zborniku tekstova objavljenom povodom četrdesete obljetnice postojanja Udruženja piše:

U zimskom semestru 1925. osnovano je u Zagrebu „Udruženje njemačkih visokoškolaca”24 (Vereinigung Deutscher Hochschüler - VDH) a u zimskom semestru 1926. „Suevia” u Beogradu. Udruženje VDH imalo je više članova od Suevie. Švapski studenti davali su prednost Zagrebačkom sveučilištu radi još postojećeg austrijskog plana studiranja, dok je Beogradsko sveučilište bilo usklađeno s francuskim redom studiranja. Usto je stanovništvo Zagreba živjelo prema usvojenoj austrijskoj tradiciji i uglavnom razumjelo njemački, kao što im je i grad bio blistavo čist i ugodan, raspolagao modernim tekovinama i doimao se doista europski, dok Beograd unatoč procvatu nakon 1918. nije mogao zanijekati svoju tursku prošlost. ${ }^{25}$

Prema drugom izvoru, u veljači 1926. godine upućeno je osamnaest poziva za osnivačku skupštinu, ali se pojavilo samo devet studenata, dok su ostali i u kasnijim prilikama smišljali svakojake isprike kako se ne bi morali odazvati. To nije obeshrabrilo osnivače te su nastavili s predanim radom na ostvarenju svoga plana tako da je u ljetnom semestru 1927. godine Udruženje brojalo već 30 članova. ${ }^{26}$ Ipak, do kraja ljetnog semestra 1927. godine Udruženje njemačkih studenata u Zagrebu bilo je tek organizacija labavog ustrojstva. ${ }^{27}$

Osim za njegovanje akademskog duha i tradicije - što se između ostaloga ostvarivalo kupnjom knjiga, časopisa i novina - usvojena pravila su predviđala da će se dio prihoda koristiti i za pružanje pomoći siromašnim članovima. ${ }^{28}$ Nije bila predviđena nikakva javna agitacija, štoviše, moglo bi se reći da su htjeli biti što manje uočljivi u široj javnosti i djelovati samo među svojim članovima. To bi moglo opravdati prigovor zbog „njemačko-nacionalnog ekskluziviteta", koji im je bio upućen 1929. godine. ${ }^{29}$

20 U Beogradu su postojala dva studentska udruženja, „Suevia” i VDH Beograd. Krajem tridesetih godina primat je preuzela „Suevia”, a VDH Beograd je, nakon priključenja članstva prvome društvu, i službeno prestao postojati. Usp. i Dušan BIBER, Nacizem in Nemci v Jugoslaviji, Ljubljana 1966., 45.

${ }_{21}$ Pravila Udruženja nemačkih studenata u Zagrebu, čl. 3. (HDA 1353: grupa VI, kut. 24, inv. br. 2350.)

22 „Die Vereinigung deutscher Hochschüler in Zagreb”, Cillier Zeitung (Celje), br. 80, 13. 10. 1927., 3.

23 Nikica BARIĆ, „Njemačka manjina u dokumentima banskih vlasti Banovine Hrvatske, 1939. - 1941.”, Časopis za suvremenu povijest, 34/2002., br. 2, 435.-470. Ovdje 453.

24 Citirani članak prijevod je teksta napisanog na njemačkom jeziku. Budući da se u arhivskim dokumentima spominje isključivo naziv „Udruženje njemačkih studenata u Zagrebu”, u ovom se radu koristi upravo ta varijanta.

25 J. MÜLLER, „O djelovanju njemačkih visokoškolaca u Zagrebu”, 199.

26 „Die Vereinigung deutscher Hochschüler in Zagreb”, Cillier Zeitung (Celje), br. 80, 13. 10. 1927., 3.

27 Sjećanje Adama Krämera objavljeno u: Josef MÜLLER-INDIA, VDH-Agram, Suevia-Belgrad: 40 Jahre, Salzburg 1964., 35.

28 Pravila Udruženja nemačkih studenata u Zagrebu, čl. 24.

29 „Ova oblast ostaje kod onoga predloga, stavljenoga u izvječtaju od 23.10.1927. (...), podnesenog u istom predmetu na naredjenje Ministarstva od 5.10.1927. (...) te potpuno usvaja mišljenje Kr[aljevskog] redar[stvenog] ravnateljstva, 
Članovima Udruženja bilo je u javnosti zabranjeno isticati bilo kakve društvene oznake. Zeleno-bijelo-zlatni grb te vrpce u istoj boji smjeli su se isticati isključivo unutar društvenih prostorija, odnosno prilikom skupština i zabava, a nikada izvan njih. ${ }^{30}$ Krajem tridesetih i početkom četrdesetih godina to će se itekako promijeniti i Udruženje njemačkih studenata u Zagrebu sudjelovat će u organizaciji velikih društvenih događaja, kao što je, primjerice, bila Njemačka večer (Deutscher Volksabend) 13. svibnja 1939. godine na Zagrebačkom zboru, u tada najvećoj zagrebačkoj dvorani. Njemačka studentska udruženja doživjet će transformaciju - iz zatvorenog, javno jedva primjetnog udruženja prerast će u svojevrsni njemački studentski pokret, koji je uključivao svoje članstvo u širokom rasponu aktivnosti od slobodnog vremena do praktične političke edukacije, doprinoseći na taj način nacionalnom osvješćiva-

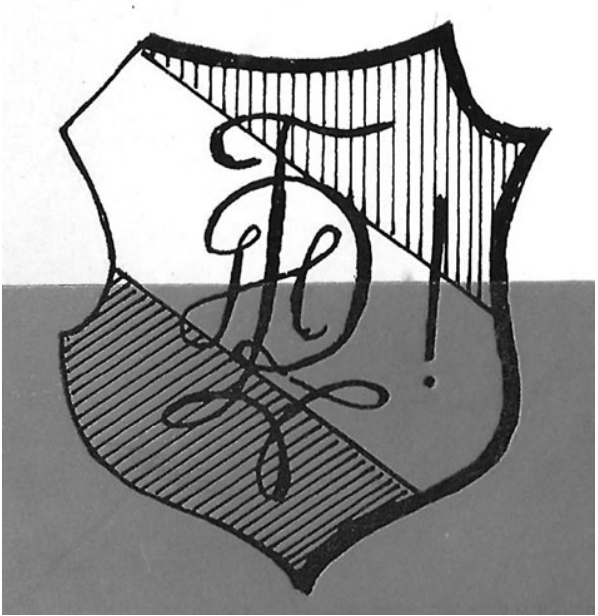

Slika 3. Grb Udruženja njemačkih studenata u Zagrebu nju Nijemaca u Kraljevini Jugoslaviji prema oficijelnom njemačkom (nacističkom) obrascu.

Dakle, iako se Udruženje formalno nije smjelo baviti politikom, članovi očito nisu bili po strani zbivanja među pripadnicima njemačke manjine u Jugoslaviji. Neki su članovi Udruženja nakon 1945. godine tvrdili da ih „1933. godina nije bitno promijenila”, da su „samo (...) htjeli biti i ostati Nijemci” te da su „poklanjali (...) vladavini Hitlera simpatiju” koju nisu „kratili ni vladavini Stresemanna i Brüninga”, u uvjerenju „da i ta nova njemačka vlada neće od [njih] ništa tražiti što bi bilo nespojivo $s$ [njihovim] državnopravnim dužnostima prema Jugoslaviji". ${ }^{31}$ Hitlerovo preuzimanje vlasti označilo je ipak početak procesa sustavne nacifikacije i njemačkih studenata u Jugoslaviji. Kao jedan od najčešćih argumenta koristile su se pritom činjenice o „teškom položaju” Nijemaca u Kraljevini Jugoslaviji, odnosno ranije u Kraljevini Srba, Hrvata i Slovenaca.

Doista, nakon Prvoga svjetskog rata stubokom se promijenio status Nijemaca u svim zemljama koje su ušle u sastav Kraljevine SHS. Iako su pariški mirovni ugovori poslije Prvoga svjetskog rata posvuda u Europi priznavali postojanje i propisivali zaštitu nacionalnih manjina, što se primjerice trebalo očitovati u mogućnosti pohađanja škola na vlastitom jeziku i prema vlastitoj želji, u praksi su im ipak bivala uskraćena neka temeljna prava. ${ }^{32}$ Bio je to slučaj i u Kraljevini Jugoslaviji. Primjerice, Nijemcima i Mađarima s pravom

da ne bi nikako bilo shodno odobriti djelovanje ovome društvu. Iz samih pravila (čl. 4. toč 3., čl. 8, čl. 19.) vidi se, da se ovo društvo oslanja na pravila i običaje njemačkih Burschenschafta. Ono bi bez sumnje svojim tjednim sastancima, društvenim znakovima it. d. it. d. dovelo do teških sukoba na univerzi, jer bi naše nacionalno društvo svakako protiv njih ustalo. Za to društvo, konačno, nema ni nikakve potrebe, jer u Z[agre]bu postoji dostatno studentskih i kulturnih i sportskih društava, tako te svaki student može da nadje društvo kakvo želi, dakako u koliko ne traži njemačko-nacionalni ekskluzivitet, kome ovdje i sa strane naših državljana nema ni najmanje biti mjesta." (HDA 1353: grupa VI, kut. 24, inv. br. 2350. Istaknuto u izvorniku.)

30 Pravila Udruženja nemačkih studenata u Zagrebu, čl. 25. Koji su razlozi uvjetovali zabranu, nije moguće zaključiti iz raspoloživih izvora.

31 J. MÜLLER, „O djelovanju njemačkih visokoškolaca u Zagrebu”, 208.

32 C. BETHKE, Deutsche und ungarische Minderheiten in Kroatien und der Vojvodina 1918-1941, 151. 
glasa onemogućeno je sudjelovanje na prvim poslijeratnim izborima jer su se, prema mirovnim ugovorima, do ljeta 1922. imali pravo preseliti u Austriju ili Mađarsku pa je vlada smatrala da im u tom razdoblju smije oduzeti politička prava. ${ }^{33}$ Neovisno o tome što se u političkom smislu položaj Nijemaca u novoj državi promijenio - kao što se promijenio i u slučaju svih drugih naroda - u društveno-gospodarskom pogledu Nijemci su posvuda bili i ostali razvijenija zajednica. ${ }^{34}$

Promjena položaja Nijemaca u Kraljevini Jugoslaviji krajem dvadesetih i početkom tridesetih godina bila je sastavni dio tadašnje službene politike promicanja u biti velikosrpskog jugoslavizma. Objava Šestosiječanske diktature 1929. kao i donošenje Oktroiranog ustava 1931. godine trebali su doprinijeti glavnom cilju proklamiranih politika: stvaranju ,jugoslavenskog naroda”. ${ }^{35} \mathrm{U}$ tom kontekstu, sva pojedinačna nacionalna obilježja, što je obuhvaćalo i nacionalne manjine, nisu smjela biti isticana. Nastojeći pred svijetom demonstrirati homogenost koju nije imala, a koja u očima vanjskog svijeta sugerira čvrstinu i snagu, ${ }^{36}$ Kraljevina SHS/Jugoslavija svoju je multinacionalnost samo nerado i napola priznavala. ${ }^{37}$

Ipak, aktivnosti Nijemaca u Jugoslaviji nikada nisu zamrle. Pokretanjem središnjeg glasila (Deutsches Volksblatt, 1919.), osnivanjem Njemačkog gospodarskog i kulturnog udruženja (Deutscher Wirtschafts- und Kulturverein, 1919.), Švapsko-njemačkog kulturnog saveza (Schwäbisch-Deutscher Kulturbund, 1920.), Središnje poljoprivredne zadruge „Agraria” (Landwirtschaftliche Zentralgenossenschaft, 1922.) te Stranke Nijemaca u Kraljevini SHS (Partei der Deutschen in Königreich SHS, 1922.) njemačka je manjina zasnovala „pravne

33 V. GEIGER, „Njemačka manjina u Kraljevini Srba, Hrvata i Slovenaca / Jugoslaviji (1918. - 1941.)”, 432.

34 O socijalnoj strukturi Nijemaca u Jugoslaviji Branko Petranović je zapisao sljedeće: „Socijalna struktura nemačke nacionalne manjine iz 1934. pokazuje da se $45 \%$ seljaka bavilo obradom zemlje u vlasništvu, $50 \%$ su bili radnici, 18\% zanatlije 3\% trgovci, 2\% intelektualci." (Branko PETRANOVIĆ, Istorija Jugoslavije 1918-1988. Knjiga prva, Beograd 1980., 58.) Vladimir Geiger preuzima sličnu statistiku iz knjige Josipa Mirnića (Josip MIRNIĆ, Nemci u Bačkoj u Drugom svetskom ratu, Novi Sad 1974.) i navodi da je struktura Nijemaca prema zanimanjima bila sljedeća: poljoprivrednici $45 \%$, radnici $30 \%$, obrtnici $18 \%$, trgovci $3 \%$ i ,intelektualci” samo $2 \%$. (V. GEIGER, „Njemačka manjina u Kraljevini Srba, Hrvata i Slovenaca / Jugoslaviji (1918. - 1941.)”, 440.) Struktura stanovništva čitave Jugoslavije po zanimanjima bila je 1931. sljedeća: prema glavnom zanimanju, udio osoba koje su se bavile poljoprivredom, stočarstvom, šumarstvom i ribarstvom iznosio je $76,3 \%$, industrijom i obrtom 10,7\%, trgovinom, kreditom i prometom $4,1 \%$, na javnu službu, vojsku i slobodna zanimanja otpadalo je $4,6 \%$, a na druga zanimanja (,rentijeri, penzioneri, radnici bez naznake posla") i nezaposlene 4,3\%. (Mijo MIRKOVIĆ, Ekonomska historija Jugoslavije, Zagreb 1968., 306.) Statistika za Vojvodinu, u kojoj je bilo najviše njemačkih „enklava” (B. PETRANOVIC̊, Istorija Jugoslavije 1918 - 1988. Knjiga prva, 58.), pokazuje da je 1931. godine od poljoprivrede, šumarstva i ribarstva živjelo $62 \%$, a od industrije $15,2 \%$ stanovništva. Osim u Sloveniji, u kojoj je prvoj skupini pripadalo 60,6\%, a drugoj čak 21,1\% stanovništva, u svim ostalim dijelovima Kraljevine Jugoslavije udio stanovništva koje je živjelo od poljoprivrede, stočarstva, šumarstva i ribartva bio je iznad 76\%. (M. MIRKOVIĆ, Ekonomska historija Jugoslavije, 308.) Osim toga, iz podataka memoranduma koji je 1940. Kulturbund uputio vladi Kraljevine Jugoslavije vidi se da su Nijemci u Vojvodini posjedovali $31,2 \%$ obradivog zemljišta, njihov udio u industrijskoj proizvodnji iznosio je $46,7 \%$, a u zanatskoj 30 do 40\%. Raspolagali su s 30,8\% bankarskog kapitala. Njemački udio u nacionalnom dohotku iznosio je 55\%. Prosječni posjed Nijemaca bio je dvostruko veći od posjeda Srba, Mađara i pripadnika drugih naroda u Vojvodini, a zemlja u posjedu pripadala je najboljoj kategoriji. (B. PETRANOVIĆ, Istorija Jugoslavije 1918 - 1988. Knjiga prva, 58.)

35 Ivo GOLDSTEIN, Hrvatska povijest, Zagreb 2008., 345.

36 Z. JANJETOVIĆ, Deca careva, pastorčad kraljeva, 64.

37 Isto, 17. Tako su, primjerice, vlasti Kraljevine SHS smatrale da bi objavljivanje broja nacionalnih manjina moglo ugroziti interese države i dati materijala njezinim neprijateljima. Zato je Ministarstvo vanjskih poslova svojim vetom odgodilo objavljivanje rezultata popisa iz 1921. godine, dok rezultati popisa po materinjem jeziku od 1931. nikad nisu službeno objavljeni za vrijeme postojanja Kraljevine Jugoslavije. (Z. JANJETOVIĆ, Deca careva, pastorčad kraljeva, 63.) 
i organizacijske okvire na planu kulturno-prosvjetnoga i informativnoga djelovanja, gospodarskoga povezivanja i unapređenja proizvodnje i plasmana proizvoda te političkoga zastupništva koje je imalo zadaću osigurati povoljniji pravno-politički položaj nacionalne manjine u državi”. ${ }^{38}$

Početkom tridesetih godina i Hitlerovim dolaskom na vlast 1933. mijenjaju se ne samo politički nego i gospodarski i kulturni odnosi u Europi. Službena jugoslavenska politika postupno se i sama prilagođavala tim promjenama. Netrpeljivost prema Nijemcima smanjena je donekle već tijekom velike svjetske krize. Nakon 1932. godine održao se još jedino jugoslavenski izvoz u Njemačku. Uvoznici njemačkih proizvoda i zastupnici njemačkih tvrtki, s druge strane, mogli su se već krajem dvadesetih godina besplatno oglašavati u berlinskom gospodarskom glasilu Deutsches Exporthandel. ${ }^{39} 1$. svibnja 1934. Njemačka je potpisala trgovinski ugovor $s$ Jugoslavijom. ${ }^{40}$ Pozitivni rezultati izvoza jedno su se vrijeme bilježili i s Austrijom. ${ }^{41}$ Sve druge europske zemlje, a naročito sile Antante, prepustile su Jugoslaviju njezinoj „sudbini” prenaseljene agrarne države. ${ }^{42}$

Nadalje, mnogi njemački i austrijski obrtnici i radnici radili su u to vrijeme, primjerice, u zagrebačkoj privredi, pogotovo na području elektrotehnike i automobilizma. ${ }^{43}$ Bilo ih je i u brojnim drugim jugoslavenskim gradovima od Vršca, Pančeva, Zemuna i Beograda do Maribora, Ptuja, Celja, Kočevja, Ljubljane i tako dalje.

Obnova hrvatsko-njemačkih, srpsko-njemačkih i slovensko-njemačkih kulturnih odnosa počela je ranije, u drugoj polovici dvadesetih godina i nije bila bez velikih opterećenja, posebno u slučaju hrvatsko-njemačkih kulturnih odnosa jer su oni nužno bili suspektni vlastima u Beogradu, u situaciji paralize hrvatsko-srpskih odnosa u Kraljevini SHS prije i poslije ubojstva Stjepana Radića. Važnu ulogu u razvoju hrvatsko-njemačkih odnosa imao je i kontroverzni Toni Schlegel, urednik dnevnih novina Morgenblatt. ${ }^{44}$

38 G. BEUS RICHEMBERGH, Nijemci, Austrijanci i Hrvati I., 138.

39 Oglas iz novina Morgenblatt (Zagreb), br. 63, 3. 3. 1928., 9.

40 G. BEUS RICHEMBERGH, Nijemci, Austrijanci i Hrvati I., 148.

41 „Die jugoslawische Landwirtschaft und Österreich”, Morgenblatt (Zagreb), br. 13, 13. 1. 1928., 5.

42 Mira KOLAR-DiMiTRIJEVIĆ, „Doprinos Nijemaca i Austrijanaca obrtništvu Zagreba do 1945. godine”, Povijesne zaobilaznice: Nijemci i Austrijanci u Hrvatskoj, (ur. Nives Rittig Beljak i Ljiljana Marks), Zagreb 2009., 12.-64. Ovdje 48. Točnije, bila je to zemlja nezavršene industrijalizacije. Usp. M. MIRKOVIĆ, Ekonomska historija Jugoslavije. i B. PETRANOVIC, Istorija Jugoslavije 1918 - 1988. Knjiga prva, posebno poglavlje „Socijalno-ekonomska osnova nove države”, 56.-85.

43 M. KOLAR-DiMITRIJEVIĆ, „Doprinos Nijemaca i Austrijanaca obrtništvu Zagreba do 1945. godine”, 48. U to doba se, primjerice, ponovno objavljuje i veliki Šamšalovićev njemačko-hrvatski rječnik. Usp. Gustav ŠAMŠALOVIĆ, Deutsch-kroatisches und kroatisch-deutsches Wörterbuch: mit besonderer Rücksicht auf Phraseologie und die wichigsten Fachausdrücke sämtlicher Zweige menschlicher Betätigung, Zagreb 1929. Inače, prvo izdanje ovoga rječnika tiskano je 1916. godine. (Enciklopedija Jugoslavije, sv. 5, Jugos-Mak, Zagreb 1962., 509.) O njemačkom utjecaju u Srbiji usp. Ranka P. GAŠIĆ, „Nemački kulturni uticaj u Beogradu tridesetih godina 20. veka”, Istorija 20. veka, 21/2003., br. 1, 31.-46.

44 Toni Schlegel je radio na osnivanju Društva prijatelja Njemačke, osnovanom u Zagrebu 1932. godine. Usp. Mira KOLAR-DIMITRIJEVIĆ, Skrivene biografije nekih Nijemaca i Austrijanaca u Hrvatskoj 19. i 20. stoljeća, Osijek 2001., 263. Inače, u članku „Doprinos Nijemaca i Austrijanaca obrtništvu Zagreba do 1945. godine” autorica navodi da je Društvo osnovano 1938. godine (str. 56). Nikica Barić u citiranom članku također navodi 1932. kao godinu osnutka. Sjedište mu je bilo na Washingtonovom trgu 3. Usp. N. BARIĆ, „Njemačka manjina u dokumentima banskih vlasti Banovine Hrvatske, 1939. - 1941.”, 454. Schlegel ipak nije doživio osnutak Društva jer je u ožujku 1929. godine ubijen ispred svoje kuće, izgleda zbog otvorenog podupiranja diktature kralja Aleksandra. O motivima i naručiteljima Schlegelovog ubojstva više u: Tomislav JONJIĆ, „Proces Hranilović-Soldin. Prilog poznavanju postanka ustaškog pokreta”, Hrvatska između slobode i jugoslavenstva: zbornik radova sa znanstvenog skupa održanog 8. i 9. siječnja 2009. u Zagrebu, (ur. Tomislav Jonjić i Trpimir Matijević), Zagreb 2009., 167.-196. Posebno str. 172. i bilj. 17 . 
Krajem 1928. godine Morgenblatt je, primjerice, u cijelosti prenio dopis iz Berlina u kojem službena Njemačka izražava zabrinutost zbog teške unutarnje situacije u Jugoslaviji. Prema njemačkom mišljenju, pogoršanje situacije bilo je posljedica atentata u jugoslavenskoj Narodnoj skupštini 20. lipnja iste godine. Za Njemačku je problem bio to što se nakon atentata nisu počele smanjivati napetosti u odnosima između Hrvata i Srba. To je pak dodaje se u dopisu - dovelo do stagnacije u njemačko-jugoslavenskim odnosima zbog koje Njemačka žali jer su prije toga oni već počeli napredovati na obostranu korist. Zbližavanju nisu zasmetale ni one nesuglasice iz kojih je proizašlo pogrešno jugoslavensko postupanje prema manjinskom pitanju. Beogradskoj Politici se također zamjerilo što se na neobjektivan način očitovala o zbivanjima u Njemačkoj. ${ }^{45}$

Raznovrsni odnosi s Njemačkom ipak su se i dalje razvijali, što je olakšalo javno djelovanje njemačke manjine. Ograničavajući se na Hrvatsku, primjerice, 1929. godine u Zagrebu je osnovano Njemačko potporno društvo (Hilfsverein) s ciljem humanitarnog djelovanja, a od 1936. godine u Osijeku je djelovalo Njemačko dobrotvorno i kulturno udruženje. U više gradova utemeljena su njemačka pjevačka društva i tome slično. ${ }^{46}$ Mnogo toga se mijenjalo i u Srbiji, naročito u vrijeme Stojadinovićeve vlade, koja je inače preferirala njemačku orijentaciju jugoslavenske vanjske politike. Njemačka je imala najveći paviljon na novoizgrađenom beogradskom Sajmištu, što je među suvremenicima imalo vrlo veliku simboličku težinu, zato što je Sajmište u to doba bilo najreprezentativniji objekt u urbanom razvitku Beograda. ${ }^{47}$ Zadnja predratna izložba bila je posvećena „novoj njemačkoj arhitekturi”, očito s ambicijom da bude primjer srpskim i drugim jugoslavenskim arhitektima. Najsloženiji su bili slovensko-njemački odnosi jer su Nijemci u Sloveniji prvi bili nacificirani, ali su nailazili i na otpor više-manje svih struja u slovenskoj politici. ${ }^{48}$

Prvi početci nacističkoga gibanja među Nijemcima u Jugoslaviji uočljivi su već i pred samo Hitlerovo preuzimanje vlasti. ${ }^{49}$ Situacija se radikalizirala pojavom Obnoviteljskog pokreta (Erneuerungsbewegung), struje sklone nacističkoj politici ${ }^{50}$ te njegovom konačnom prevlašću u Kulturbundu 1939. godine. S pojavom nacizma Kulturbund je sve više pažnje počeo posvećivati političkom zadatku okupljanja Nijemaca i „spašavanja njemačke manjine od odnarođivanja". ${ }^{51}$ U Jugoslaviji se u novim prilikama otvaralo sve više njemačkih škola, posebno u selima i gradovima gdje je njemačko stanovništvo bilo brojnije, a gdje nisu imali vlastite škole ili odjeljenja. Osnivalo se sve više njemačkih čitaonica, obilno opskrbljenih knjigama, časopisima i ostalim tiskovinama iz Trećeg Reicha. ${ }^{52}$

Udruženje njemačkih studenata u Zagrebu, koje je nastalo sredinom dvadesetih godina kao uistinu skromna zajednica s ciljem poticanja druženja među studentima njemačke na-

$\overline{45}$ „Deutschland und Jugoslawien. Eine sehr bemerkenswerte Berliner Erklärung”, Morgenblatt (Zagreb), br. $299,30$. 10. 1928., 2.

46 O njemačkim udruženjima u Hrvatskoj više u: Ivo GOLDSTEIN, Židovi u Zagrebu 1918-1941., Zagreb 2004., 434.-435. i G. BEUS RICHEMBERGH, Nijemci, Austrijanci i Hrvati I., 136.-143.

47 Usp. Jovan BAJFORD, Staro sajmište. Mesto sećanja, zaborava i sporenja, Beograd 2011., 28.-30.

48 O Nijemacima u Sloveniji u to doba usp. Božo REPE, „Intelektualci, političke stranke i grupacije u Sloveniji u predvečerje Drugog svetskog rata”, tekst objavljen u ovom zborniku radova. Usp. i Michael WEDEKIND, „Znanost i politika. Restrukturiranje Slovenije, 1939.-1945.”, Intelektualci i rat 1937.-1947. Zbornik radova s medunarodnog skupa Desničini susreti 2011., (ur. Drago Roksandić i Ivana Cvijović Javorina), Zagreb 2012., 83.-96.

49 D. BIBER, Nacizem in Nemci v Jugoslaviji, 43.

50 V. GEIGER, „Njemačka manjina u Kraljevini Srba, Hrvata i Slovenaca / Jugoslaviji (1918. - 1941.)”, 436. O sukobima unutar Kulturbunda usp. i G. BEUS RICHEMBERGH, Nijemci, Austrijanci i Hrvati I., 156.-159.

51 V. GEIGER, „Njemačka manjina u Kraljevini Srba, Hrvata i Slovenaca / Jugoslaviji (1918. - 1941.)”, 434.

52 Isto 
rodnosti u Zagrebu, postalo je s vremenom organizacija pod punom kontrolom Obnoviteljskoga pokreta, kojim su dominirale skupine mladih nacificiranih Nijemaca. ${ }^{53}$

Ideološke razlike među dvjema najutjecajnijim strujama u Kulturbundu („stari” i „obnovitelji") bile su donekle i generacijski uvjetovane. Starije generacije članova, koje su odrasle u Austro-Ugarskoj, našle su se nasuprot mlađim generacijama, koje su u Prvome svjetskom ratu dijelile svoja ratna iskustva s njemačkim vojnicima. Još mlađi su često studirali na austrijskim i njemačkim sveučilištima i izravno se upoznali, pored ostalog, i s nacističkim idejama. ${ }^{54}$ Prema nekim izvorima, dvadesetih je godina u Austriji i u Weimarskoj Republici studirala polovica volksdojčerskih studenata iz Jugoslavije, često između 200 i 250 studenata godišnje te su se tamo uključivali u mnoge njemačke organizacije. ${ }^{55}$

Jugoslavenske su vlasti očito bile svjesne kakav je sve utjecaj imalo to „zajedničko socijalizacijsko iskustvo". ${ }^{56}$ Tako je, na primjer, banska uprava u Novom Sadu još u lipnju 1933. godine predložila Ministarstvu unutrašnjih poslova u Beogradu da ograniči mogućnosti studiranja studenata njemačke narodnosti u Njemačkoj jer su, prema njihovim saznanjima, u Jugoslaviju unosili nacionalsocijalističku ideologiju. ${ }^{57}$ Doista, od sredine tridesetih godina, službeni njemački VDA (Volksbund für das Deutschtum im Ausland) davao je stipendije isključivo podupirateljima Obnoviteljskog pokreta. ${ }^{58}$

Iako formalno nije bilo dijelom Kulturbunda, Udruženje njemačkih studenata u Zagrebu bilo je uključeno u mrežu institucija i organizacija koja je oko njega nastajala. ${ }^{59}$ Očito i zbog sve bolje međusobne koordinacije njemačkih institucija i organizacija, vlasti su sve više sumnjale u pravi cilj Udruženja njemačkih studenata u Zagrebu. Unatoč tome što je prema odobrenim pravilima njegova zadaća bila „širenje društvenosti i prosvete među članovima”, „glavni je i stvarni cilj, da se čuva nemačka nacionalna svest. Članovi su nacionalsocijalistički nastrojeni i na njihov rad se stalno pazi" ${ }^{60}$ Još je početkom kolovoza 1938. godine zagrebačka policija pretražila prostorije Udruženja i pritom zaplijenila sve knjige, revije i korespondenciju društva. ${ }^{11}$ Uprava policije u Zagrebu u više je navrata predlagala da se udruženje raspusti ,jer je bilo utvrđeno, da se njihovim listom (Student im Volk - I.C.J. ${ }^{62}$ vrši

Isto, 436.

54 D. BIBER, Nacizem in Nemci v Jugoslaviji, 43.

55 C. BETHKE, Deutsche und ungarische Minderheiten in Kroatien und der Vojvodina 1918-1941., 297. Međutim, ne smije se smetnuti s uma da je „mamac” za studiranje u inozemstvu mogla biti i raznovrsnija ponuda studija, a ne isključivo pristajanje uz nacističku ideologiju.

56 C. BETHKE, Deutsche und ungarische Minderheiten in Kroatien und der Vojvodina 1918-1941., 297.

57 Isto, 382 .

58 Isto, 298. Godine 1881. osnovan je Allgemeiner Deutscher Schulverein. Cilj te organizacije bilo je širenje i podupiranje njemačkog školstva u čitavom svijetu. To se postizalo osnivanjem ili očuvanjem njemačkih škola, vrtića i knjižnica u inozemstvu te stipendijama za studij u Njemačkoj. Njegovu ulogu je 1908. preuzeo Verein für das Deutschtum im Ausland, a 1938. nacificirana Volksdeutsche Mittelstelle. D. BIBER, Nacizem in Nemci v Jugoslaviji, 43.

59 Carl Bethke pod pojmom mreže (Netzwerk) podrazumijeva „redovitu, ciljanu i usuglašenu suradnju međusobno povezanih čvorova, bez formalne hijerarhije." Usp. C. BETHKE, Deutsche und ungarische Minderheiten in Kroatien und der Vojvodina 1918-1941., 283.

60 HDA 1358: grupa XI, kut. 29, inv. br. 2776.

61 D. BIBER, Nacizem in Nemci v Jugoslaviji, 175.

62 Prema nekim izvještajima, prvi je broj objavljen već 1938. godine. U sjećanjima Haralda Scale navedeno je da je list tog naslova tiskan već 1936. godine: „Najprije se pisao na matricama, zatim umnožavao rukom, a kasnije tiskao. Prilikom jednoga pretresa u Bačkoj zaplijenjeno je nekoliko primjeraka tog lista, koji se nije izdavao prema odredbama jugoslavenskog zakona o tisku. Zbog toga smo Richard Stieb i ja uhićeni u ljeto 1938. ili 1939. (...) Nakon našeg saslušanja, koje je trajalo nekoliko sati, ponovno smo pušteni na slobodu.” Usp. J. MÜLLER-INDIA, VDH-Agram, Suevia-Belgrad: 40 Jahre, 51. Moguće je da se radilo o nekoj vrsti biltena ili letka, slabije kvalitete od kasnijeg glasila. Usp. izvještaj Redarstvenog ravnateljstva od 25. kolovoza 1938. ili izvještaj Uprave policije u Zagrebu od 30. siječnja 1939. (HDA 1358: grupa XI, kut. 29, inv. br. 2881.) 
nacional-socijalistička propaganda”. Međutim, određeno je „da se pretstavnicima društva saopći, da će udruženje biti raspušteno, ako se ne bi pridržavalo svojih društvenih pravila". ${ }^{63}$ Posebno im je zasmetalo što se list „štampa samo na nemačkom jeziku” te što je njegov cilj „propaganda nemačkog nacionalsocijalizma u redovima naših studenata nemačke narodnosti”. ${ }^{64} \mathrm{U}$ promijenjenim prilikama nakon proglašenja Banovine Hrvatske odustalo se od raspuštanja Udruženja. ${ }^{65}$

Prema policijskom izvješću može se zaključiti da je Student im Volk bio mnogo više od lista kakav je trebao biti prema odobrenim limitima. Neobično je bilo to što je glasilo koje je bilo namijenjeno „uskom krugu čitača, dakle samo članovima njemačkog studentskog udruženja, radi čega se štampa[o] u ograničenom broju”, ${ }^{66}$ preciznije, u 500 primjeraka, već svojim prvim brojem izazvalo velik interes u čitavoj njemačkoj zajednici u Kraljevini Jugoslaviji pa i preko njezinih granica. Zagrebačke njemačke novine Deutsche Nachrichten odmah su ga „najtoplije preporučile svim sunarodnjacima” i pozvale ih na pretplatu. ${ }^{67}$

\section{Dirigirana nacifikacija}

Očito je politički kontekst u Jugoslaviji stvarao dovoljno prostora za mogućnost dirigirane mobilizaciju njemačke manjine u Kraljevini Jugoslaviji, a naročito studenata njemačke narodnosti, u skladu s nacističkim načelima, prilagođenima različitim prilikama u zemlji. U toj mobilizaciji nikada se nije prelazilo preko negativnih iskustava iz dvadesetih godina, ali, $s$ druge strane, nastojalo se iskoristiti sve mogućnosti koje su se otvarale sa sve ubrzanijim poboljšanjem službenih i raznovrsnih drugih odnosa s Njemačkom, naročito nakon nacističkog preuzimanja vlasti.

Početkom tridesetih godina započinje „novo doba” i u razvitku Udruženja njemačkih studenata u Zagrebu. U tim promjenama važan je bio izravni utjecaj nacificiranog VDA. Njemačke organizacije su i ranije davale stipendije studentima njemačke narodnosti iz Jugoslavije za studij u Njemačkoj, ${ }^{68}$ ali je početkom tridesetih godina VDA počeo organizirati „obuku” studenata i u Jugoslaviji, na kojoj su studenti nacistički indoktrinirani. Već od 1933. godine u Zagrebu je djelovao Paul Claus, član NSDAP-a i opunomoćenik VDA za Jugoslaviju. ${ }^{69}$ Kao njemački državljanin nije mogao biti službeni omladinski vođa Kulturbunda, ali je bio njegov stvarni vođa. ${ }^{70}$ Sredstvima koje je dobio iz Njemačke izgradio je tabor na Pohorju, gdje je u jesen 1934. vodio tromjesečne nacističke tečajeve s 96 polazni-

\footnotetext{
HDA 1358: grupa XI, kut. 29, inv. br. 2881.

Isto.

5 HDA 1358: grupa XI, kut. 29, inv. br. 2776.

6 HDA 1358: grupa XI, kut. 29, inv. br. 2779.

6 Deutsche Nachrichten (Zagreb), br. 13, 18. 3. 1939., 3.

6 Usp. bilj. 58.

69 Nakon završenog studija ekonomije u Leipzigu, 1926. godine upisao se na Sveučilište u Beogradu, a od 1933. studirao je pravo u Zagrebu. Claus se kasnije prisjećao svoje djelatnosti u Zagrebu: „Iz Udruženja njemačkih studenta u Zagrebu dolazili su važni impulsi za provođenje nacionalsocijalističke misli. (...) Osnovali su brojne omladinske grupe Schwäbisch-Deutscher Kulturbunda u glavnim područjima naseljenima [Nijemcima] i dali mnoge borce za prevlast pokreta Obnovitelja." (Arnold SUPPAN, Jugoslawien und Österreich 1918-1938. Außenpolitik im europäischen Umfeld, Wien - München 1996., 727.)

70 Pravila Udruženja nemačkih studenata u Zagrebu, čl. 5.; usp. D. BIBER, Nacizem in Nemci v Jugoslaviji, 49.
} 
ka, koji su nakon završetka tečaja bili angažirani u promicanju programa Obnoviteljskog pokreta. $^{71}$

Clausovo djelovanje nije bio pojedinačni slučaj. Skupine njemačkih studenata obilazile su Nijemce izvan Reicha. Upoznavale su pa i istraživale povijest, jezik i kulturu njemačke manjine u Jugoslaviji, ali je njihova glavna zadaća bila promicanje nacističkih shvaćanja. Neki među njima otvoreno su svjedočili o svojim uvjerenjima. Primjerice, prilikom boravka u Zagrebu 1933. godine pojedini članovi jedne od tih skupina javno su nosili znak kukastog križa na svojoj odjeći, a u Gorjanima pokraj Đakova iste su godine dijelili letak s Hitlerovim govorom. ${ }^{72}$ Redakcija zagrebačkog časopisa Židov već je od 1933. godine upozoravala da se u legalnim „kulturnim” društvima njemačke manjine u Jugoslaviji vrši sustavna nacionalsocijalistička propaganda, uz materijalnu potporu iz Trećega Reicha. Potkraj 1935. godine policija je saznala da se u podružnicama Kulturbunda omladinci zaklinju na „hakenkrojclersku” zastavu i polažu zakletvu da se neće ženiti sa Srpkinjama, Mađaricama i Židovkama. ${ }^{73}$

Postojanje složene manjinske organizacijske strukture, usmjeravane iz Trećeg Reicha, bilo je presudno za uspjeh procesa nacifikacije jer politička mobilizacija inače nije spontani proces. ${ }^{74}$ Neophodni resursi bili su pritom zajamčeni. Prema Esmanu, treba razlikovati „domaće” i „vanjske” resurse: „demografska i socijalna struktura skupine koju treba mobilizirati”, „pitanje njezine kohezije, njezinih communicative skills”, ali i „mogućnost pristupa 'vanjskim' resursima, primjerice u domovini" određuju kako će se mobilizacija razvijati. ${ }^{75}$ Nijemci su već od ranih 1920-ih godina imali relativno gustu mrežu manjinskih institucija i organizacija, koje su neovisno o promjenama nakon 1929. ipak ne samo „preživjele” nego se i nakon 1933. godine, prije ili kasnije, umrežile po nacističkim obrascima i pod izravnom nacističkom kontrolom. ${ }^{76}$

U 1930-im planski se stvaralo nove „Vođe”. Udruženje njemačkih studenata u Zagrebu bilo je hijerarhijski organizirano, a Willi Badl je od 1938. do 1941. kao Landesstudentenführer bio neprijeporni vođa. Esman naglašava istovremenu važnost kako kohezije tako i natjecanja među pojedincima u vodstvu organizacije za njezino uspješno djelovanje, naročito kada je glavni cilj masovna politička mobilizacija članstva. ${ }^{77}$ Badl je bio vrlo uspješan i kao studentski vođa koji povezuje ljude, ali i kao vođa koji autoritativno prednjači u političkoj mobilizaciji. Naime, unutar Udruženja njemačkih studenata u Zagrebu postojala je manja skupina bivših studenata (Altakademiker) koja se nije slagala s Badlovom politikom. Protiveći se ukidanju tradicionalnih akademskih boja i vrpce, to jest znakova pripadnosti studentskom udruženju, oni su se u stvari protivili nacifikaciji. Isti je smisao imalo i njihovo protivljenje omasovljivanju Udruženja. Badl je uz pomoć sebi odanih ljudi svladao

71 D. BIBER, Nacizem in Nemci v Jugoslaviji, 49. Slične tečajeve za njemačku omladinu iz Jugoslavije (Kraljevine SHS), posebno za omladinu iz Slovenije, još od 1928. vodio je dr. Helmut Carstanjen u dvorcu Sv. Martin kod Graza. (Isto, 44.) O djelovanju dr. Helmuta Carstanjena više u: M. WEDEKIND, „Znanost i politika. Restrukturiranje Slovenije, 1939.-1945.", 83.-96.

72 I. GOLDSTEIN, Židovi u Zagrebu 1918-1941., 434.

73 Isto, 435.

74 M. J. ESMAN, Ethnic politics, 245.

75 C. BETHKE, Deutsche und ungarische Minderheiten in Kroatien und der Vojvodina 1918-1941., 31.

76 Kulturbund je bio zabranjen 1924. godine na zahtjev ministra prosvjete Svetozara Pribićevića. Obnoviteljska skupština održana je 1927. (G. BEUS RICHEMBERGH, Nijemci, Austrijanci i Hrvati I., 148.) Nakon uspostavljanja Šestosiječanjske diktature ponovno je došlo do stagnacije u radu, ali je vlada već u kolovozu 1930. dozvolila Kulturbundu nesmetano društveno djelovanje, a nova pravila su bila odobrena u travnju 1931. (D. BIBER, Nacizem in Nemci v Jugoslaviji, 49.)

77 D. BIBER, Nacizem in Nemci v Jugoslaviji, 29. 
njihov otpor, označavajući ih kao „proizvod jednog ranijeg, liberalnog visokoškolskog odgoja” i „prevladanog vremena”. ${ }^{78}$

Ukidanje znakovlja trebalo je pridonijeti nacifikaciji, odnosno, kako se tvrdilo, lakšem uklapanju u njemačku narodnu zajednicu, $s$ već ranije izrečenom tezom da studentska društva nisu nikakvi „intelektualni kružoci”, nego „mjesta odgoja” u kojima svi članovi postaju svjesni svoje "prve i najveće dužnosti”: službe svom narodu. ${ }^{79} \mathrm{Zbog}$ toga je bilo potrebno ukloniti sve što je bilo neprimjereno „novom dobu” i što je sprečavalo uspješan mobilizacijski rad. Akademske boje i vrpce su stoga odbačene kao ,izraz onog vremena koje smo danas nadživjeli i na mjesto kojega je došlo jedno novo, veličanstvenije [vrijeme]." ${ }^{\prime 0}$ To nipošto nije bila posebnost njemačkoga studentskog pokreta u Jugoslaviji. Događalo se to po uzoru na promjene u Trećem Reichu, gdje se od sredine tridesetih godina počelo raditi na „uniformiranju” studenata. Studentska udruženja su se raspuštala ili su bila prisiljena raspustiti se, a nadzor je preuzimao Nacionalsocijalistički njemački studentski savez ( $\mathrm{Na}$ tionalsozialistischer Deutscher Studentenbund). ${ }^{81}$

Da bi se ostvarilo glavni cilj, u časopisu Student im Volk primjenjivale su se različite „strategije i taktike” (Esman), s nakanom da se studenti potaknu aktivno sudjelovati u „životu narodne zajednice”, prema nacističkom poimanju. Bilo da se radilo o korištenju simboličkih motiva uglavnom folklorističke naravi ili o izravnom apeliranju na osjećaj dužnosti prema njemačkoj narodnoj zajednici, važno je bilo samo jedno: stvoriti „novog studenta”, a time i „novog čovjeka”, neraskidivo vezana za zajednicu iz koje potječe i s kojom se identificira, neovisno o društvenom podrijetlu. Zbog svega toga, list nije pisao samo o „tipičnim” studentskim temama. Doduše, iako one nisu nestale iz njegova sadržaja, bile su prezentirane na način koji je također služio političkoj mobilizaciji (npr. prikazi iskustava sa skijanja, s organiziranih sudjelovanja u žetvama, sa sportskih aktivnosti). Bilo je i tekstova o seljacima, narodnim običajima, povijesti, srednjoškolskom obrazovanju, zapošljavanju i tako dalje, a svi su - izravno ili neizravno - bili u funkciji promicanja nacističke ideologije. Velik dio časopisa zauzimali su tekstovi normativne naravi, kao što je već istaknuto, nerijetko preneseni iz glasila u Trećem Reichu, u kojima su se studentima davale smjernice svjetonazorske naravi, uputstva za rad itd.

\section{1. Student u narodu}

Najvažnije osobine svakog Nijemaca, a time i studenta, prema Student im Volk, mogu se svesti pod jedan zajednički nazivnik - svijest o zadaćama prema svom narodu:

Novo je vrijeme pred nas postavilo nove zahtjeve, a zadaće koje su zadane nama studentima kao punopravnim članovima naše narodne zajednice, imperativno su zahtijevale od nas da od svakog druga (Kamerad) tražimo najveće zalaganje (Einsatz) i najtežu službu (Dienst). ${ }^{82}$

Stoga je Badl već u prvom broju listu Student im Volk namijenio ulogu „pozivatelja na djelovanje" (Rufer zum Einsatz). ${ }^{83}$ Budući da je, prema njegovim riječima, većina mladih

\footnotetext{
Willi BADL, „Student im Volk”, Deutsche Nachrichten (Zagreb), br. 7, 4. 2. 1939., 2.

W. BADL, „Die Grundlinien unserer Arbeit”, 2.

Isto.

81 Usp. Holger ZINN, Das studentische Kameradschaftswesen im Dritten Reich unter besonderer Berücksichtigung der Bünde von DL und VC, Würzburg 2001.

82 W. BADL, „Die Grundlinien unserer Arbeit”, 1.

83 Willi BADL, „Der zweite Jahrgang 'Student im Volk”, Student im Volk, 2/1940., br. 1, 1.
} 


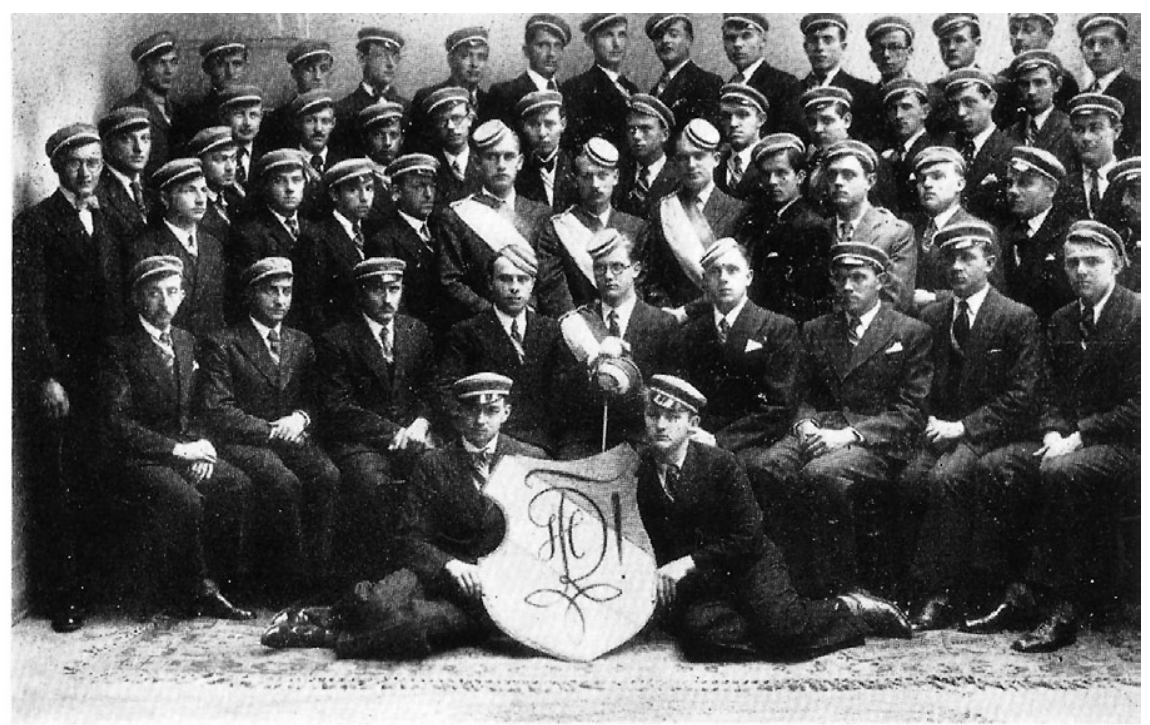

Slika 4. Članovi Udruženja njemačkih studenata u Zagrebu u ljetnom semestru 1934. godine

Nijemaca - pritom očito misleći na Nijemce u Jugoslaviji - odrasla bez ikakvog oblika nacionalnog institucionalnog uključivanja, zbog čega su bili nacionalno neosviješteni, trebalo ih je osvijestiti. To je značilo uvjeriti ih da biti student ne znači uživati u „akademskim slobodama", već odgojem postati borac za narod (völkischer Kämpfer), to jest školovanjem se osposobiti za rad u narodu (Volkstumsarbeit). Zbog toga je svatko po završetku studija trebao steći „zatvorenu sliku (...) narodne skupine” i biti upućen u „sva pitanja u vezi s domovinom”. Pritom je ideologijski najvažniji bio koncept „dužnosti”. Cilj nije bio odgajati „mozgovne akrobate” (Gehirnakrobaten) nego „muškarce koji će, kad se vrate u svoje rodno selo, dati uvjerljiv dokaz novog nazora". ${ }^{84}$

Često se isticala povezanost sa selom, napose rodnim, a ona je bila vidljiva već i na naslovnici glasila Student im Volk. Veliku pozornost državne cenzure, koja je inače pratila i ovo glasilo, izazvala je upravo njegova naslovnica. ${ }^{85}$ Zbog nje je krajem studenoga 1939. godine Badl bio pozvan na obavijesni razgovor. ${ }^{86}$ Naime, grb s ukrštenim mačem i lopatom otisnut na naslovnoj stranici Student im Volk podsjećao je na odlikovanje kojim su u to doba bili odlikovani graditelji Siegfriedove linije. ${ }^{87}$ Badl je negirao bilo kakvu povezanost s nacističkom simbolikom:

Znak koji je otisnut na naslovnoj strani lista Student im Volk simbolizira borbu kolonista Nijemaca u Vojvodini za zemlju. Mač na tom znaku predstavlja odnosno simbolizira borbu protiv uzurpatora zemlje, a lopata na tom znaku predstavlja faktičnu borbu za zemlju. Prema historiji prije dolaska Srba, Hrvata i Nijemaca na teritorij današnje Vojvodine, obitavali

W. BADL, „Die Grundlinien unserer Arbeit”, 1.

85 Sačuvani primjerci glasila Student im Volk nalaze u se u Hrvatskom državnom arhivu u Zagrebu u Zbirci špijunaža i peta kolona. Naslove „sumnjivih” tekstova cenzori su podvlačili crvenom olovkom.

86 U ovom se izvještaju ime pojavljuje u obliku Villim Badl. („Zapisnik od 29. XI. 1939. sastavljen u uredu Redarstvenog ravnateljstva u Zagrebu”, HDA 1358: grupa XI, kut. 29, inv. br. 2776.) Usp. bilj. 16.

87 Siegfriedova linija je bio naziv njemačke utvrđene fronte prema Francuskoj, Belgiji i Nizozemskoj. Gradila se od 1938. do 1945. Bila je duga 600 kilometara i sastojala se od 22.000 fortifikacijskih objekata. (http://enciklopedija. lzmk.hr/clanak.aspx?id=36219) 


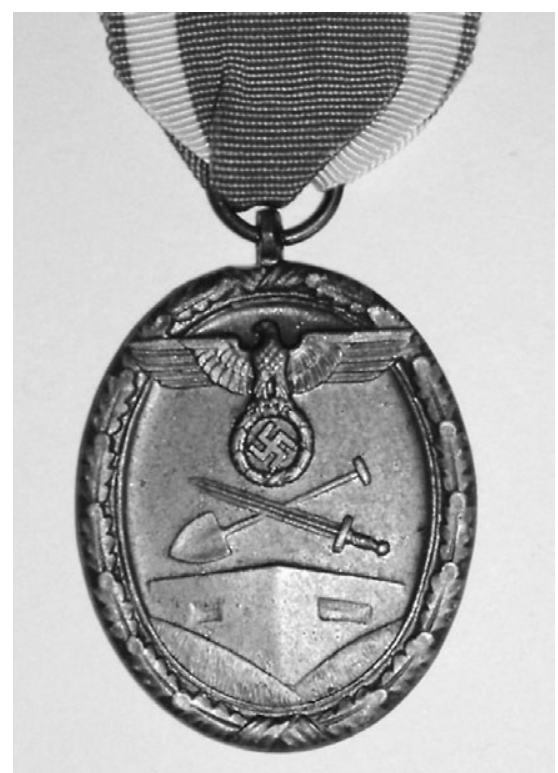

Slika 5. Odlikovanje dodijeljeno graditeljima Siegfriedove linije

su Turci odnosno činili su česte prepade na tu zemlju, pa su se gore spomenuti narodi protiv njih stalno borili i nisu im dali svoju zemlju, to je bila dakle borba za opstanak, borba protiv invazije stranaca, tuđina. ${ }^{88}$

Osim toga, Badl je naglasio da je njihov znak nastao mnogo ranije nego odlikovanje koje je dr. Fritz Totd podijelio graditeljima Siegfriedove linije. Naime, prvi broj lista Student im Volk objavljen je 1. ožujka 1939. godine, a predložak za sam znak bio je svakako izrađen već mjesec dana ranije. Badl je zaključio da su oni „već upotrebljavali znakove 9 mjeseci prije, nego što su takovi znakovi dani radnicima za zasluge za gradnju Siegfriedove linije, a 4 mjeseca prije, nego što je uopće uvedeno u Njemačkoj to odlikovanje za radnike". ${ }^{99} \mathrm{Nije}$ propustio spomenuti ni činjenicu da nije upoznat s time jesu li navedeni znakovi uopće slični. ${ }^{90}$

Teško je povjerovati da je Badl uspio uvjeriti vlasti $\mathrm{u}$ apsurdnost optužbi za sličnost $s$ nacističkim simbolom. Vrlo je vjerojatno da su vlasti pristale na ovakav ishod zbog svjesnog popuštanja. ${ }^{91}$ Primjera je bilo mnogo. Tako je u lipnju 1939. godine Ministarstvo unutrašnjih poslova iz Beograda poslalo Kraljevskoj banskoj upravi „naređenje o postupanju s licima” koja pozdravljaju sa „Heil, Sieg heil” i „Heil Hitler”. Naime, u Ministarstvu su zaključili da se „u poslednje vreme (...) kod nemačkog življa u našim severnim krajevima" moglo uočiti da pozdravljaju podizanjem desne ruke te da pritom izgovaraju „hajl, sig hajl”, „što ne sadrži još ništa inkriminirajuće”. Međutim, „ako se ovi pozdravi čine u cilju simbolične političke manifestacije, što je najčešće slučaj, ili sa tendencijom izazivanja, - onda postoji opasnost da se reakcijom jednog dela građana naruši javni red i mir." Zato je takve pojave trebalo suzbijati u samom začetku. Nadalje, dodaje se u zaključku, „pozdrav 'hajl Hitler' ne može se kod nas (u Kraljevini Jugoslaviji - I.C.J.) smatrati pozdravom, pošto se isti u Nemačkoj upotrebljava kao obligatna zaključna formula u zvaničnoj prepisci, a usvojen je od nemačkih građana i u njihovom privatnom međusobnom opštenju. Sem toga, pozdrav 'hajl Hitler' ne označuje samo pripadnost jednoj stranoj političkoj partiji i njenoj ideologiji, nego i odanost i građansku privrženost šefu nemačke države... Sem toga, neumesna upotreba imena šefa susedne države može izazvati neželjene incidente i time ugroziti dobre odnose između nas i Nemačke." Zato je Ministarstvo obvezalo Kraljevsku bansku upravu da dostavlja „mesečne izveštaje o broju kažnjenih lica za ove krivice”. Bilo je još sličnih pojedinačnih incidenata. Početkom rujna 1939. godine Kotarsko načelstvo u Osijeku izvijestilo je da se pozdrav Sieg Heil koristio tijekom proslave žetve Švapsko-njemačkog prosvjetnog saveza 20. kolovoza u Ernestinovu prilikom dolaska Branimira Altgayera, prijeratnog vođe Kulturbunda za Slavoniju i Hrvatsku, a nekoliko go-

\footnotetext{
HDA 1358: grupa XI, kut. 29, inv. br. 2776.

Isto.

Isto.

91 Vlada Milana Stojadinovića (1935.-1938.) vodila je politiku poboljšanja jugoslavensko-njemačkih odnosa. Više o tome: B. PETRANOVIĆ, Istorija Jugoslavije 1918-1988, Knjiga prva, 256.-309.
} 
dina kasnije vođe Njemačke narodne skupine u Nezavisnoj Državi Hrvatskoj. U mnogim službenim izvještajima može se ipak pronaći mišljenje da se radilo o pojedincima odnosno o „izvesnim elementima” koji „svojim radom nastoje da zloupotrebe nemačke manjinske priredbe, organizacije i štampu u cilju propagiranja i manifestovanja jednog čisto političkog držanja, koje sasvim izlazi iz okvira dopuštenog kulturnog života nemačke manjine, a često predstavlja širenje iredentističke propagande, uperene protiv postojećeg pravnog poretka i državne celine, ispunjujući pri tome sve uslove inkriminacije". ${ }^{2}$

Dakle, policija, pogotovo tajne službe, pratile su (pro)nacističke aktivnosti, ali je pravosuđe očigledno reagiralo tek od prilike do prilike. ${ }^{93}$ Tako se i na početku istrage o naslovnici Student im Volk smatralo da znak ima propagandni značaj „i to vjerojatno u korist jedne strane ratujuće države" te da ga treba zabraniti. Nakon što su saslušali Badla, koji je nekoliko dana kasnije donio i naslovnicu novina Völkischer Beobachter s prikazom odlikovanja graditeljima Siegfriedove linije, Redarstveno ravnateljstvo u Zagrebu zaključilo je nakon usporedbe znakova „da se oni bitno razlikuju, a zajedničko im je jedino to, što imadu jedan i drugi ukršteni mač i lopatu, koji je mač i lopata dosta sličan na obim znakovima, ali su ukršsteni u protivnom pravcu". ${ }^{4}$

Unatoč slikovitom objašnjenju o nastanku znaka na naslovnici Student im Volk i poricanju bilo kakve veze s nacističkim simbolima, neka pitanja ipak ostaju otvorena. Prvo, iako se dodjela odlikovanja za Siegfriedovu liniju uistinu dogodila nakon tiskanja prvog broja Student im Volk, trebalo bi istražiti je li njegov nacrt već bio objavljen u njemačkom tisku. Poznato je da su članovi Udruženja njemačkih studenata u Zagrebu čitali taj tisak. ${ }^{95}$ Drugo, čak i ako se odbaci veza između znaka na naslovnici Student im Volk i odlikovanja graditeljima Siegfridove linije, pitanje je zašto je opisani motiv izabran za naslovnicu studentskog glasila. Kao što je već rečeno, njegov cilj nije bio samo obavještavati o zbivanjima među studentima njemačke narodnosti. Korištenje seljačkih običaja i folklorističke simbolike bilo je jedno od sredstava nacističke propagande. ${ }^{96}$ Naime, u to doba ponovno su oživjele pseudoromantičarske predodžbe o seljaštvu kao „korijenu narodnog stabla”, ${ }^{97}$ „zdravom temelju nacije i rase" 98 i ,izvoru krvi”, ${ }^{99}$ koje su svoj puni izražaj dobile u ideologiji „krvi i tla” (Blut und Boden). Treće, znak na naslovnici Student im Volk koristio se jednom prilikom ranije iste godine na sportskim dresovima Udruženja njemačkih studenata u Zagrebu. Šablone za znakove napravio je Lotar Mülhausen, a izrađivali su se u tvornici Jugosvila u Mariboru. ${ }^{100}$ Zanimljivo je obratiti pozornost na mjesto tiskanja ovih znakova. Badl je bio zavičajan u Mariboru pa je mogao imati različite motive za odabir navedenog mjesta. Međutim, Maribor je uz Celje bio neupitan centar okupljanja omladinaca njemačke narodnosti „koji stoje u vezi sa nacionalističkim organizacijama u Nemačkoj, naročito

22 HDA 1358: grupa XI, kut. 29, inv. br. 2774.

93 I. GOLDSTEIN, Židovi u Zagrebu 1918-1941., 437.

94 Redarstveno ravnateljstvo u Zagrebu, Politički otsjek, 2. prosinca 1939. Banskoj vlasti Banovine Hrvatske, Odjeljku za državnu zaštitu, HDA 1358: grupa XI, kut. 29, inv. br. 2776. Podvukla I.C.J.

95 J. MÜLLER, „O djelovanju njemačkih visokoškolaca u Zagrebu”, 208.

96 Anette BLASCHKE, „Ideologische Mobilisierung im “völkischen Kernland”, Workshop „Mobilisierung im Nationalsozialismus”, Jena, 10./11. März 2010. Glavne teze izlaganja dostupane na http://www1.uni-jena.de/ns-gaue/workshop_2010.htm. Ovdje citirana str. 4.

97 Werner CONZE, „Bauer. Bauernstand, Bauerntum”, Geschichtliche Grundbegrife, sv. 1, Stuttgart 1992., $407 .-439$. Ovdje 437.

98 Isto, 438.

99 Isto, 407.

100 Zapisnik Redarstvenog ravnateljstva u Zagrebu, 2. 12. 1939., HDA 1358: grupa XI, kut. 29, inv. br. 2776. 
u Gracu, koje imaju specijalne zadatke u Jugoslaviji." ${ }^{101}$ Upravo je predstojništvo mjesne policije u Mariboru potaklo istragu o spornim znakovima, ${ }^{102}$ nezadovoljno jačanjem nacističkog utjecaja među Nijemcima, koji se očitovao u uređivačkoj politici listova Deutsche Nachrichten ${ }^{103}$ i Student im Volk. Bilo je inače prigovora upućenih na različite zagrebačke službene adrese da „ovdašnja (zagrebačka - I.C.J.) cenzura nije dovoljno informirana o njemačkoj opasnosti”. ${ }^{104}$ Ministarstvo unutrašnjih poslova u Beogradu reagiralo je na optužbe i zatražilo od vlasti Banovine Hrvatske da redovito dostavljaju podatke o pisanju svakog „lista na njemačkom jeziku, koji izlazi na teritoriju nadzora”. ${ }^{105}$

Povezanost studenta i seljaka trebala je imati važnu ulogu u homogenizaciji njemačke narodne zajednice, pri čemu su se načelno zanemarivale sve staleške razlike. Trebalo je pokazati da su obje skupine, za koje se nerijetko mislilo da su se nalazile na suprotnim polovima društvenog raslojavanja, organski upućene funkcionirati zajedno. Da bi se to postiglo, od 1935. godine, primjerice, u ljetnim su mjesecima studenti organizirano odlazili na selo pomagati seljacima u žetvenim poslovima. Studenti su se na taj način zbližavali sa seljacima i razvijali osjećaj povezanosti sa seljačkom zemljom, shvaćajući da je seljaštvo „hranitelj nacije". ${ }^{106}$

Osim uvjeravanja studenata o potrebi takvih akcija, nesumnjivo je velik napor iziskivalo i uvjeravanje seljaka da studenti nisu nikakva "gospoda” koja se libe teškoga fizičkog rada i zapravo dolaze k njima ljetovati. Studenti su im, prema Student im Volk, trebali dokazati da dolaze

(...) seljaku, njemačkom seljaku da bi se na radu na polju približili jedan drugome i upoznali; da bi vlastitim očima vidjeli kako živi slavonski Nijemac; da bi doživjeli njegov jad i njegovu radost; i još nešto: da bi doživjeli narodno zajedništvo (Volksgemeinschaft). ${ }^{107}$

Isto tako, trebali su svojim zalaganjem uvjeriti seljake da je došlo vrijeme studenata spremnih za rad i da ima ,još mnogo za orati i sijati, da bi se jednom moglo žeti”, ali i navesti ih da zaključe da su upravo to studenti kakve oni trebaju. ${ }^{108}$

Iako su postojali prigovori da se studenti bave „svim drugim stvarima koje oduzimaju vrijeme, samo ne studijem", ${ }^{109}$ ni u jednom se trenutku nije odustalo od zacrtanog cilja studenta koji će sa svojim sunarodnjacima dijeli životnu sudbinu. To je, uostalom, bio i jedan od razloga pokretanja časopisa Student im Volk:

Ne želimo oko našeg časopisa okupljati stalež akademičara' ${ }^{110}$ da bismo ga izdvojili iz njegove narodne grupe. Naprotiv! Želimo taj stalež ponovno vratiti našem narodu. Želimo u

\footnotetext{
${ }_{101}$ Odjel za državnu zaštitu izvještava o njemačkoj akciji u našoj zemlji, 29. 11. 1939., HDA 1358: grupa XI, kut. 29, inv. br. 2877.

102 Isto.

${ }^{103}$ Deutsche Nachrichten izdavali su „zagrebački Nemci koji se okupljaju oko ‘Švapsko-nemačkog prosvetnog saveza”. (HDA 1358: grupa XI, kut. 32, inv. br. 2903.)

${ }_{104}$ HDA 1358: grupa XI, kut. 29, inv. br. 2776.

${ }^{105}$ HDA 1358: grupa XI, kut. 32, inv. br. 2904.

106 A. BLASCHKE, „Ideologische Mobilisierung im 'völkischen Kernland””, 3.

107 L. K., „Landdienst”, Student im Volk, 2/1940., br. 1, 10.

108 Isto.

109 „Am Rande bemerken wir”, Student im Volk, 2/1940., br. 1, 15.-16. Ovdje 16.

110 Akademičar - pov. arh. onaj koji pohađa višu školu ili fakultet, doslovno akademiju; student. (V. ANIĆ, Rječnik hrvatskoga jezika, 15.$)$
} 
njemu probuditi spremnost na djelovanje, iz njega učiniti korisnog člana našeg narodnog tijela. ${ }^{111}$

„Korisni član narodnog tijela” mogao je postati samo onaj tko je ozbiljno shvatio koja mu je uloga namijenjena i tko je bio spreman vršiti zadane dužnosti.

\section{2. Student kao "voda"}

Jesu li svi studenti bili svjesni svojih zadaća? Očito nisu. Riječima Jakoba Awendera, vođe Obnoviteljskoga pokreta, „akademski obrazovani građanin je uvijek vođa, dobar ili loš" ${ }^{112}$ Zato je bilo

(...) žalosno gledati kakve su vođe većina akademski obrazovanih građana. Oni, koji bi morali stajati na čelu u borbi za našu njemačku narodnost (Volkstum), biti uzorni svojim primjerom, uglavnom se drže po strani. ${ }^{113}$

Mogle su se čuti još i oštrije kritike, primjerice, poput kritike Hansa Jacoba Heina:

Naši akademičari su u našoj dosadašnjoj kratkoj povijesti u potpunosti zakazali na svim područjima, nisu riješili nijednu njima dodijeljenu zadaću, do nedavno nisu ni bili svjesni tih zadaća, a nisu u potpunosti još ni danas! ${ }^{114}$

Bilo je, doduše, onih koji su, prema istom autoru, ostvarili zapažena postignuća pa čak i djelovali kao perjanice na svojim područjima, ali se ipak radilo samo o pojedincima:

Što su postigli, postigli su jedino i isključivo zbog svijesti da su svom narodu dužni da to postignu - ne kao akademičari, već kao njemački ljudi. Da, s obzirom na tadašnje stanje, može se mirno reći da to nisu postigli jer su bili akademičari, nego da su to postigli usprkos tome. ${ }^{115}$

Razlozi tom zakazivanju, dodaje se u kritici, ne leže u studentskim vođama i metodama rada, već je „materijal koji se mora obraditi višestruko neprimjeren”. Naime, velik je problem bio što je „društvena pokretljivost” i dalje bila vrlo slaba te se često događalo da studiraju samo oni koji su trebali nastaviti obiteljsku tradiciju fakultetskog obrazovanja, čak i uz manjkave intelektualne sposobnosti. Budući da je stalež akademičara, „zahvaljujući (...) liberalističkoj hijerarhiji” bio „bolji” sloj, mnogi su studirali „samo zato što je i gospodin papa studirao”, a ovaj nije mogao dopustiti da njegov „bolji' sinčić padne u 'niži' sloj i da živi (...) primjerice kao pošteni obrtnik ili trgovac”. ${ }^{116}$ Prigovori su bili upućeni i djeci sa sela. Prigovaralo im se da kreću na studije iz koristoljublja, da bi mogli „pokazati svijetu da [su] u mogućnosti postati 'gospodin'”. Prema Heinu, sve je to bila posljedica „dosljedne nakaznosti one bolesne udobnosti, koja najvećim dijelom degenerira u bijeg od posla, odgovornosti, zalaganja i borbe". ${ }^{117}$ Umjesto očeve diplome i debelog novčanika, glavni

\footnotetext{
111 Richard STIEB, „Warum eine Studentenzeitschrift?”, Student im Volk, 1/1939., br. 2, 10.-11. Ovdje 10.

112 Isto, 11.

113 Isto.

114 Hans Jacob HEIN, „Das Problem der Auslese bei unseren Studenten”, Student im Volk, 2/1940., br. 1, 2.-5. Ovdje 3. Prema navodu iz članka, isti je tekst već objavljen u glasilu Volksruf.

115 H. J. HEIN, „Das Problem der Auslese bei unseren Studenten”, 3. Istaknuto u izvorniku.

116 Isto, 4 .

117 Isto, 4.-5.
} 
kriterij kod upućivanja djece na studij trebala je biti „prirodna nadarenost u kombinaciji s poštenim karakterom”. ${ }^{118}$ Samo se tako mogla provesti „zdrava selekcija” (gesunde Auslese) i od predstavnika svih društvenih slojeva stvoriti nova elita, sposobna da vodi njemački narod. Takva je selekcija bila nužna jer je studij, prema uobičajenim nacističkim shvaćanjima, omogućavao pristup najmoćnijem oružju - „intelektualnom oružju”, a ono je, ako se njime ispravno rukuje, „opasnije i razornije” od svakog drugog oružja jer „prodire mnogo dublje, ubija i uništava duh i dušu". Budući da se posjedovanje tog oružja ne može regulirati dozvolama, kao u slučaju vatrenoga, ovakva selekcija trebala je spriječiti da ,intelektualne šeprtlje ili čak zločinci” dođu u posjed „tog najopasnijeg ljudskog oružja (...), ukoliko očev novčanik ispunjava potrebne uvjete". ${ }^{119}$

Iako se uredništvo Student im Volk ogradilo od „nekih” tvrdnji iznesenih u ovom član$\mathrm{ku}$, sama činjenica da su mu poklonili tri stranice i da su ga u cijelosti prenijeli iz novina Volksruf, ${ }^{120}$ upućuje na to da je postojala potreba za jasno definiranim stavovima o ovoj temi. Osim toga, nije li upravo otvorenost studentskog statusa za pripadnike svih društvenih slojeva mogla znatno doprinijeti tome da se studenti prestanu smatrati izdvojenom društvenom skupinom pa da uistinu budu shvaćeni kao dio naroda, što je i bio moto glasila Student im Volk?

Naposljetku, završni odlomak citiranog članka kao da sažima ciljeve tadašnjeg vodstva njemačkih studenata: nakon što se provede opisana „selekcija”, motivi za studij neće više biti financijske i utilitarističke prirode, a cilj studiranja neće više biti samo stjecanje diplome da bi se potom mogao voditi ugodan i bezbrižan život. Naprotiv,

(...) imat ćemo studente kojima studij znači zadovoljenje unutrašnjeg poriva, koji ih tjera da usavršavaju svoje prirodno znanje i urođenu nadarenost kako bi ih kasnije što korisnije mogli staviti u službu zajednice i toj će zajednici, koja im je otvorila put do najvišeg obrazovanja, doživotno biti dužni. I naposljetku ćemo dobiti akademičare koji će u svom položaju i statusu vidjeti višu obvezu, koji u [statusu] akademičara neće vidjeti samo zanimanje, nego u najvećoj mjeri poziv. ${ }^{121}$

Može se, dakle, reći da je ispunjavanje dužnosti prema svom narodu bila najvažnija zadaća svakog njemačkog studenta i (budućeg) akademski obrazovanog građana. No, tko je činio narod, odnosno prema kome je točno trebalo ispuniti dužnost i od čega se ona sastojala?

Reinhard Koselleck referira na jednu definiciju iz 1933. godine, prema kojoj je narod zajednica (Gesamtheit) nositelja povijesnog života, određenih krvlju, tlom i kulturom, što zapravo znači da se pojmovi nacionalne (Nationalstaat) i narodne države (völkischer Staat) ne moraju uvijek podudarati. ${ }^{122}$ I u tekstovima objavljenim u Student im Volk razlikuju se Nijemci iz Reicha i Nijemci koji žive izvan njega. Međutim, svi oni ravnopravno čine jedan narod. Ponekad se zbog takva shvaćanja uloga Nijemaca izvan Reicha čak i jače naglašava-

\footnotetext{
118 Isto, 5 .

119 Isto, 3.-4.

120 Tjednik Volksruf: Organ für völkische Erneuerung izlazio je u Pančevu od 1934. do 1941. godine. Urednici su bili dr. Jakob Awender i Gustav Halwax, a redakcijske prostorije nalazile su se u Awenderovoj kući. Bilo je to zaprvo glasilo Obnoviteljskog pokreta. (http://ruma.donauschwaben.net/download/dokumentation/Doku_II_10.pdf; pristup stranici 13. 1. 2013.)

121 H. J. HEIN, „Das Problem der Auslese bei unseren Studenten”, 5.

122 Citirano prema: Reinhart KOSELLECK, „Volk', 'Nation', 'Nationalismus' und 'Masse' 1914 - 1945”, Geschichtliche Grundbegriffe, sv. 7, Stuttgart 1992., 389.-439. Ovdje 410.
} 
la. Obično im se „priznavalo” da su bili nositelji ideje o „velikom carstvu svih Nijemaca” i da je ta ideja izvan Njemačke ostajala živa u različitim razdobljima. ${ }^{123}$

Narod se, $\mathrm{k}$ tome, u nacističkoj ideologiji naglašeno shvaćalo u organskom smislu, kada je riječ o odnosu pojedinca i naroda: „Mi smo u narodu. Narod misli i osjeća, propada u nama i mi živimo i umiremo u narodu." ${ }^{24}$ Drugim riječima, narod nije određen državnim teritorijem jer granice ionako određuju „povijesni razvitak i strana samovolja”. ${ }^{125}$ Narod je - u ovom slučaju njemački - tamo gdje su Nijemci. Narod može napredovati samo ako se živi „u narodu i s narodom", ${ }^{126}$ ali - moglo bi se dodati - i za narod. Povijesne okolnosti i „diktatori mira"127 doveli su do toga da je njemačko narodno tijelo (Volkskörper, Volksleib) oslabilo. Srećom, organizam ima sposobnost regeneracije. Kao što se organizam može smatrati potpuno zdravim samo ako su mu svi organi zdravi, tako i narod može „ozdraviti” jedino uz „zdrave” pripadnike koji su svjesni potrebe „ozdravljenja”. Da bi narod „ozdravio”, nužna je „bezrezervna poslušnost prema unutrašnjim zakonima narodnog bića (Volkssein)" ${ }^{128}$ i predan rad:

Ako je nekoć i bilo moguće narodu reći da ili ne, ili se pak moglo biti nacionalno ili antinacionalno nastrojen, danas više ne možemo koristiti tu terminologiju. (...) Izjasnimo li se da smo članovi u organskom narodnom tijelu, tada je isključena svaka dobrovoljnost; nužno nam je predodređena dužnost u narodu. ${ }^{129}$

Međutim, „tamo gdje se zahtijeva poslušnost, mora postojati zapovjednik” jer „sljedba (Gefolgschaft) može opstati samo pod vodstvom”. ${ }^{130}$ Vodstvo se pritom moralo „regrutirati” iz redova studenata, "pionira društva” 131 i akademski obrazovanih građana:

Kome to treba biti jasnije, nego upravo onima (...) čiji je poziv da upale baklju realne i stvarne spoznaje i da osvjetljavaju put: akademičarima. ${ }^{132}$

Da bi pak akademičari mogli postati vođe, morali su ispuniti neke preduvjete, a stjecanje akademske titule bio je tek jedan od koraka na tom putu. Toni Mahlberg, utjecajniji član Udruženja njemačkih studenata u Zagrebu, žalio je zbog premalog broja studenata njemačke narodnosti u Kraljevini Jugoslaviji. ${ }^{133}$ Objašnjavajući zašto je tome tako, to jest zašto se mladi Nijemci ne odlučuju studirati - čak i oni koji bi mogli podnijeti troškove studija - ustvrdio je da je to posljedica njihovog „teškog položaja” kao pripadnika nacionalne manjine. Smetalo ga je što i oni koji se odluče za studij često biraju profesije „s kojima se

$\overline{123}$ Dr. Helmut BAUERSFELD, „Studentische Außenarbeit des Reiches”, Student im Volk, 1/1939., br. 2, 2.-4. Ovdje 2.

124 Johann BARON, „Zeitgemässe Erkenntnis”, Student im Volk, 1/1939., br. 2, 4.-5. Ovdje 4.

125 Dr. H. BAUERSFELD, „Studentische Außenarbeit des Reiches”, 2.

126 J. BARON, „Zeitgemässe Erkenntnis”, Student im Volk, 1/1939., br. 2, 4.

127 Isto.

128 Isto.

129 Isto.

130 Isto, 5.

131 Dr. Gustav Adolf SCHEEL, „Überfülle europäischer Aufgaben”, Die Bewegung, br. 9/10, 16. 5. 1942., 3.

132 J. BARON, „Zeitgemässe Erkenntnis”, Student im Volk, 1/1939., br. 2, 5.

133 Dr. Toni MAHLBERG, „Berufsplanung”, Student im Volk, 1/1939., br. 2, 5.-6. Ovdje 5. Akademske godine 1931./32. na sveučilištima u Zagrebu, Beogradu i Ljubljani studirao je 371 student njemačke narodnosti, 1932./33. 366, 1933./34. 390, 1934./35. 379, 1935./36. 392. Njima se treba pridodati još 200 do 250 studenata godišnje koji su studirali izvan Jugoslavije. (C BETHKE, Deutsche und ungarische Minderheiten in Kroatien und der Vojvodina 1918-1941., 297.) Na popisu iz 1931. godine njemački jezik kao materinski navelo je 499.969 osoba (uključujući oko 10.000 Židova). (V. GEIGER, „Njemačka manjina u Kraljevini Srba, Hrvata i Slovenaca / Jugoslaviji (1918. 1941.)", 43.) 
ne može ništa započeti”, odnosno koje nisu jamčile mogućnost sigurne egzistencije. Zato je savjetovao da se biraju „praktični predmeti” i da se uče strani jezici. ${ }^{134}$

Međutim, iako je fakultetsko i stručno obrazovanje bilo itekako važno, ono nije bilo dovoljno. Richard Stieb je to isticao na sljedeći način:

Znamo da naša narodna zajednica treba odlične stručnjake. (...) Ali znamo, i to uopće ne možemo dovoljno naglasiti, da samo stručno obrazovanje ne može biti dobro obrazovanje. ${ }^{135}$

Oni koji su „samo-stručnjaci”, prema Stiebu, „zakržljali [su] ljudi bez ikakve osobne vrijednosti, ispunjeni uskogrudnošću i duhovnom beživotnošću”, „ljudi koji su izgubili kontakt sa svojom okolinom i nisu pronašli nadomjestak”. ${ }^{136}$ Tom tipu „samo-stručnjaka” trebalo je suprotstaviti umnog radnika (der geistige Arbeiter), dakle nekoga tko posjeduje i stručno znanje, ali i umijeće i spremnost da radi za boljitak svog naroda:

Takav će se čovjek iskazati u svim životnim situacijama, zahvaljujući svojoj izgrađenoj ličnosti bit će osposobljen za velika postignuća. Kako u svom užem stručnom području tako i u širokom okviru intelektualnog i političkog života naše narodne zajednice moći će ostvarivati rezultate $i$, što je važnije, bit će uvijek spreman na to. ${ }^{137}$

Izbjegavanje izvršavanja ovako shvaćenih imperativnih zadaća i stajanje „po strani” bilo je ravno izdaji naroda i nije se smjelo tolerirati:

Njemački akademičari! Za nas nema stajanja po strani! Tko nije s nama, taj je protiv nas! Loše vođe nisu samo oni koji su protiv nas, protiv vlastitog naroda, nego i autsajderi, zanovijetala, svadljivci, pametnjakovići (...) koji se smatraju predobrima da bi se uključili u veliki front čitavog naroda. Želimo uništiti nadmenost; ona pripada minulom vremenu. $\mathrm{Ne}$ poznajemo „uglednike”, poznajemo samo radnike i parazite. Kod određivanja vrijednosti čovjeka priznajemo samo jedno: njegov učinak. Znamo tisuću otrcanih „razloga” za držanje podalje, znamo da je mnogima „nemoguće” surađivati, da se pred njima gomilaju brda „otpora”. Ne može postojati razlog i nema razloga koji može poštenog njemačkog čovjeka odvratiti od njegove dužnosti. Svatko mora na svom mjestu ispuniti svoju dužnost. Uistinu se ne očekuje od svakoga da vodi narodnu zajednicu! Ipak, svatko mora na svom mjestu vršiti svoju službu. ${ }^{138}$

\section{3. Student i rat}

Početak Drugog svjetskog rata označavao je cezuru u uređivačkoj politici glasila Student im Volk. Vidljivo je to u prvom broju njegovog drugog godišta, objavljenom u ožujku 1940. godine. Na prvoj stranici otisnut je tekst vođe Kulturbunda Seppa Janka, iz kojeg se vidi da je rat zakucao i na vrata Nijemaca u Jugoslaviji:

Nitko tko je njemačke krvi i tko se smatra pripadnikom njemačkog naroda ne vjeruje da se može osloboditi sudbine svoga naroda i da nije dužan biti uočljiv i aktivan član svoje narodne organizacije (Volkstumsorganisation). Odavno su prošla vremena u kojima se prema liberalističkim shvaćanjima moglo odlučivati kamo se pripada. Ovdje je sudbina neumoljiva

\footnotetext{
${ }_{134}$ Dr. Toni MAHLBERG, „Berufsplanung”, 5.

135 R. STIEB, „Warum eine Studentenzeitschrift?”, 11.

136 Isto.

137 Isto.

138 Isto. Istaknuto u izvorniku.
} 
i svakoga poziva da položi račun, da mu se postavi pitanje o izjašnjavanju: izjašnjavaš li se za svoju narodnu zajednicu i želiš li joj dati doprinos tako što ćeš ispunjavati svoje dužnosti ili se ne izjašnjavaš za nju? I želiš li da se drugi žrtvuju i za tebe? Jer jednom će možda doći vrijeme kad će onaj koji se izjašnjava biti preslab da sam podnosi sve žrtve; i tada će [ga] sudbina pogoditi još žešće. Svima onima koji ne žele ispuniti svoje dužnosti prema narodnoj skupini (Volksgruppe) glasno izričem ozbiljan 'memento'. Postoji najviše mjerilo vrijednosti ljudi i naroda: imaju li sposobnost i volju za žrtvu. Kad mi Nijemci stupimo među narode, tada ti narodi moraju znati da nemamo namjeru u tome zaostajati ni za kim i da bismo se sramili kad bi bilo drugačije. Žrtva je tako sveta riječ da bi bilo loše dati joj bilo kakav izazivački ton. Narodi koji su sami spremni na žrtvu, pazit će da ne dirnu u ono što je drugima životno nužno i sveto. To je stav koji omogućuje stvaran redoslijed odnosa od naroda do naroda. I na temelju te spoznaje, dragi njemački sunarodnjače (Volksgenosse), želimo se zavjetovati pred našim precima, pred idućim naraštajima i pred nama samima: naš život je dužnost prema narodu da bi mu se osigurala vječnost! ${ }^{139}$

Budući da Kraljevina Jugoslavija tada još nije bila ušla u rat, urednici su znali da ne smiju otvoreno veličati rat i pozivati na sudjelovanje u njemu. Zbog toga se u citiranom tekstu nijednom ne spominje rat, ali je bilo i više nego očito da se od Nijemaca u Jugoslaviji očekivalo da se priključe i pridonesu njemačkoj pobjedi: ako oni sada ne pomognu Nijemcima u Reichu, što mogu očekivati Nijemci u Kraljevini Jugoslaviji kad rat jednom dođe i do Kraljevine? A to je, sudeći prema ovom tekstu, očito bilo samo pitanje vremena jer su se interesi vlastitog naroda, ugroženi od drugih naroda, morali braniti pod svaku cijenu. Cilj nacističke indoktrinacije, dirigirane iz Trećeg Reicha još od ranih tridesetih godina, bilo je kondicioniranje Nijemca i pripremanje za trenutak kad će morati podnijeti žrtvu za obećani boljitak njemačkog naroda.

„Žrtva” (Opfer) je bila jedan od pojmova koji se u glasilu Student im Volk pojavljivao u sličnoj učestalosti kao i pojmovi „dužnost” (Pflicht) i „služba” (Dienst) jer dužnost često podrazumijeva i žrtvu. Potrebno je s time u vezi ukazati na dva značenja pojma žrtve: lat. sacrificium i lat. victima. Dok „sakrificijelne žrtve” uglavnom dobrovoljno daju svoj život, očekujući da će se njihova žrtva poštovati, ${ }^{140}{ }^{\text {}, v i k t i m o l o s ̌ k a ~ z ̌ r t v a ” ~ p a s i v n i ~ j e ~ o b j e k t ~ n a s i l j a ~}$ lišen obrane. „Sakrificijelna žrtva” za svoje djelovanje očekuje i dobiva potvrdu unutar vlastite zajednice. ${ }^{141} \mathrm{Od}$ njemačkih studenata tražilo se žrtvovanje u smislu prve kategorije: dobrovoljno žrtvovanje za narodnu zajednicu, koja će pak tu žrtvu znati cijeniti. Konačna nagrada svima bit će njezin budući procvat.

Kad se govorilo o žrtvovanju, u predratnim brojevima Student im Volk nije se pisalo o umiranju za više ciljeve. Žrtva je ponajprije podrazumijevala prilagodbu vlastite svakodnevice potrebama njemačke zajednice, čak i nauštrb svoje udobnosti. Od studenata i akademski obrazovanih građana tražilo se, na primjer, da žrtvuju svoje slobodno vrijeme i iskoriste ga za rad u zajednici. ${ }^{142}$ Studenti su se tijekom ljetnih praznika morali staviti na raspolaganje mjesnom ogranku Kulturbunda i to pod prijetnjom teške kazne u slučaju neposluha. ${ }^{143}$ Kao što je već rečeno, rad na zemlji bio je odgojno vrlo važan: nakon 1935. godine mnogi

139 Student im Volk, 2/1940., br. 1, 1. Unatoč dotadašnjoj praksi tiskanja tekstova u dva zgusnuta stupca, bez nepotrebnih bjelina, tekst vođe Kulturbunda Seppa Janka tiskan je u mnogo „prozračnijem” obliku, od jednog do drugog ruba stranice, što također govori u prilog njegove važnosti.

140 Alaida ASMAN, Duga senka prošlosti, Beograd 2011., 87.

141 Isto, 92.

142 W. BADL, „Die Grundlinien unserer Arbeit”, 3.

143 Isto, 2. 
su studenti ljetne praznike provodili po Slavoniji, osnivajući ili pomažući pri osnutku mjesnih grupa Kulturbunda, pridonoseći da „ponovno probuđeni sunarodnjaci” steknu „osjećaj povezanosti svih Nijemaca neovisno o staleškim razlikama”." ${ }^{144}$

Nakon izbijanja rata od njemačkih su se studenata počela zahtijevati još veća odricanja i upravo se tu vidi umijeće pisanja članaka kojima je glavna svrha bila da ih se čita „između redaka" i da se na indirektan način uputi poziv za sudjelovanje u ratu i bespogovorno izvršavanje Führerovih naređenja, bez obzira radi li se o izravnom sudjelovanju u bitkama ili o poslovima kao što su, primjerice, istovar ugljena, čišćenje snijega ili istrebljivanje žohara te rad $\mathrm{u}$ industrijskim pogonima. ${ }^{145} \mathrm{O}$ ovom potonjem se ipak moglo slobodnije pisati jer su eventualne prigovore jugoslavenskih vlasti uvijek mogli pobiti argumentom da se radi o „svakodnevnim” poslovima koji se obavljaju i u mirnodopsko doba, ali i u ratnim uvjetima. Ipak, neupitno je da se radilo o pripremama za rat i o svim oblicima uključivanja stanovništva u ono što će se u suvremenoj historiografiji nazivati totalnim ratom.

U tom se duhu može tumačiti i naoko „bezazleni” tekst o doživljajima sa skijanja u Sloveniji. Taj se događaj pritom ne pokazuje kao obična zimska razonoda, već se u njemu uočava veliki mobilizacijski potencijal. Naime, da bi studenti koji su pošli na skijanje uopće došli do svog cilja, planinske kolibe, morali su prijeći naporan put, uspinjući se strmim stazama, a četverosatni marš i dosegnuti cilj „probudili [su] duh i tijelo za novi život." ${ }^{446}$ Iako su bili iscrpljeni, nisu posustajali u sportskim aktivnostima ni drugo jutro jer je „strogi gospodin 'šef' neumoljiv". ${ }^{147}$ Nije čudo da su ti tjelesni napori, koji su zahtijevali veliku izdržljivost, doveli do toga da su neki putem zastali ili se izgubili, ali zahvaljujući „zabrinutom gospodinu 'šefu' osobno”, dodao je autor teksta, organizirala se potraga za „izgubljenom ovčicom” pa je „izgubljeni sin” pronađen i vraćen tamo gdje bi trebao biti. Kult vođe (Führerprinzip) propagirao se u još jednom tekstu napisanom po sličnoj matrici: trčanje kroz šumu u hladno zimsko jutro, po vijugavim stazama, ali uvijek u jednoj liniji, skretanje pojedinaca s puta $\mathrm{i}$ - ono najvažnije - dobar i sposoban vođa skupine koji putem izgubljene članove vraća na pravi puti put samo su neki od prisutnih motiva u tekstu potpisanom samo inicijalima R.S., što bi moglo značiti da se radilo o Richardu Stiebu. ${ }^{148}$

Teške tjelesne aktivnosti i „čeličenje” bile su zapravo priprema za rat, odnosno početak ratne obuke: „Uklopiti se u momčad (Mannschaft), suzdržavati se od gunđanja čim nešto pođe po zlu, moći podnijeti nešto, odlučno se boriti za pobjedu i moći dostojanstveno podnijeti poraz - to nam je važno. Borbenost i disciplina znače nam više nego sportske lovorike."149

U istom broju Student im Volk objavljen je i prvi izravni ratni prilog: pismo s bojišta anonimnog vojnika iz Trećeg Reicha. U njemu do izražaja dolaze svi važniji pojmovi: krv, tlo i čast. CCitatelji pred očima imaju sliku mladog vojnika koji u proljeće svoga života s nestrpljenjem očekuje poziv u rat, samo kako bi se odužio domovini, a da pritom ne razmišlja o opasnostima koje rat nosi - ili, bolje rečeno, utjelovljuje ideje koje se kriju iza krilatice $D u$ bist nichts, dein Volk ist alles! (Ti si ništa, tvoj narod je sve!) Ponosan što je dobio priliku

\footnotetext{
144 Isto.

145 Dr. Gustav Adolf SCHEEL, „Die Aufgabe und Durchführung der studentischen Dienstpflicht”, Student im Volk, 2/1940., br. 1, 14.-15. Ovdje 15.

146 K. K., „Schi-Heil!”, Student im Volk, 2/1940., br. 1, 11.-12. Ovdje 12.

147 Isto.

148 R. S., „Frühsport”, Student im Volk, 2/1940., br. 1, 10.-11. Ovdje 11.

149 Isto.
} 
sudjelovati u ratu, razmišlja o ranijim ratovima, još od doba Napoleona, u kojima je sudjelovala njemačka mladež. To se pismo može shvatiti u još jednom kontekstu - u kontekstu mita o mladeži spremnoj na žrtvu za domovinu, čak i pod cijenu vlastitog života, stvorenog i razvijanog tijekom Prvoga svjetskog rata, nakon bitke koju kao primjer spominje i sam autor pisma - bitke kod Langemarka. ${ }^{150}$ Langemark je s vremenom postao simbol za službu narodnoj zajednici, jedan od konstruktivnih stupova u militariziranom nacističkom društvu, koje je nastojalo „oživjeti” sjećanje na časnu ulogu njemačkih vojnika, posebno studenata odnosno mladeži:

(...) bili su to njemački studenti, koji su 1914. zajedno s cvijetom čitave njemačke mladeži u Flandriji i Belgiji jurišali na neprijateljske linije pjevajući Deutschlandlied, ${ }^{151}$ zauzeli selo Langemark i žrtvovali svoj život za domovinu. Njihova žrtva, njihov juriš i njihova pobjeda ostaju vječno urezani u pamćenju njemačkih studenata. Naši mladi drugovi (Kameraden) dali su svoj život vjerni studentskoj tradiciji i studentskom odgoju (...). ${ }^{152}$

Kao primjer studenta koji je shvatio i prihvatio namijenjenu ulogu u ratu može se uzeti i sam Willi Badl. On je svoju odanost Trećem Reichu izrijekom potvrdio 1939. godine, četiri godine prije pogibije na bojišnici, izjavivši da je spreman učiniti „sve, čak i ono najviše (...) za narod i Führera i biti bezuvjetan borac za čast njemstva i veličinu Reicha”, ${ }^{153}$ a nekrolog objavljen u glasilu Die Bewegung s ponosom je isticao njegovu žrtvu. ${ }^{154}$

Neovisno o svim suzdržanostima, uvršteni članci ne ostavljaju mjesta sumnji da se radilo o svenjemačkoj mobilizaciji u ratnom naporu u koji je ušao Treći Reich. Može se stoga zaključiti da je posljednji analizirani broj Student im Volk svojim intonacijama pa i sadržajima - što neizravno, što izravno - sav u ratnoj vrućici.

\section{Umjesto zaključka: student kao intelektualac}

U svijetu u kojem je pojedinac bio podređen kolektivu to jest zajednici, postavlja se pitanje je li uopće postojao prostor za bilo kakav oblik intelektualnog djelovanja i jesu li u njemu uopće mogli nastati intelektualci u smislu osoba s visokom naobrazbom koje se bave umnim radom i javno djeluju kao moralna i humana snaga u društvu? ${ }^{255}$

${ }_{150}$ Mit o Langemarku (njem. Langemarck) povezan je s bitkom koja se odigrala 10. studenoga 1914. godine u Belgiji, desetak kilometara sjevernije od Ypresa. Radilo se o neuspješnom njemačkom pokušaju proboja, u kojem je poginulo oko 2000 njemačkih vojnika. Već idućeg dana njemački je tisak prenio obavijest o veličanstvenoj pobjedi njemačkih trupa, sastavljenih uglavnom od pripadnika mladeži, koji su u napad krenuli pjevajući „Deutschland, Deutschland über alles”. Osim što je vijest o pobjedi bila lažna, prešućivalo se i da se bitka odigrala bliže mjestu Bixschote, a isticao se samo Langemark, najvjerojatnije zato što je ime zvučalo „njemački”.

151 Treća strofa Pjesme Nijemaca (Das Lied der Deutschen ili Das Deutschlandlied) danas je službena njemačka himna. Prva strofa pjesme započinje poznatim stihom o Njemačkoj iznad svega ostaloga (Deutschland, Deutschland über alles).

152 Tekst Gustava Adolfa Scheela, vođe njemačkih studenata u Trećem Reichu, objavljen u novinama Innere Front 7. 11. 1941. pod naslovom „Die Erfüllung von Langemarck. Inbegriff des ewigen Sturm- und Opfergeistes deutscher Jugend”. Citirano prema: Arndt WEINRICH, Der Weltkrieg als Erzieher. Jugend zwischen Weimarer Republik und Nationalsozialismus, Essen 2012., 289.

153 Die Bewegung: Zeitung der deutschen Studenten, br. 11, srpanj 1943., 8.

154 „Willy Badl zum Gedächtnis”, Die Bewegung: Zeitung der deutschen Studenten, br. 2, kraj veljače 1944., 10.

155 V. ANIĆ, Rječnik hrvatskoga jezika, 317. 
U tri analizirana broja glasila Student im Volk riječi s korijenom „intelekt” pojavljuju se relativno rijetko u usporedbi s nekim drugim pojmovima. Za lakšu orijentaciju, navedimo samo neke od njih. „Dužnost” (Pflicht) se spominje 19 puta, a isti se korijen pojavljuje još u nekoliko navrata, bilo kao prvi ili drugi dio složenice. "Žrtva” (Opfer) je iskorištena deset puta, glagol „žrtvovati” (opfern) dvaput, a po jednom „požrtvovnost” (Opferwille) i „krvna žrtva” (Blutopfer). „Služba” (Dienst) se spominje 24 puta, „obveza služenja” (Dienstpflicht) 22 puta, a ima još i nekoliko drugih izvedenica istog korijena.

U skupini riječi izvedenih od „intelekt”, najzastupljenija je imenica „inteligencija” (Intelligenz, 9), a slijede „intelektualac” (Intellektuelle, 2), „sloj inteligencije” (Intelligenzschicht, 2), pridjev ,intelektualni” u značenju „umni” (intellektuell, 1) i ,intelektualni kružoci” (Intellektuellenzirkel, 1).

U jednom od tekstova objavljenih u Student im Volk autor se žalilo na nedostatak „prave njemačke", narodne inteligencije (völkische Intelligenz). Uzroke tome vidio je u mađarizaciji kojoj su Nijemci u Ugarskoj bili izloženi u 19. stoljeću: naime, građanska inteligencija (bürgerliche Intelligenz) brzo se mađarizirala u valovima mađarskih „narodnih preporoda” i tek je manji dio njemački nastrojenih (deutschgesinnt) ljudi pokušavao utjecati na svoje zemljake i probuditi u njima osjećaj nacionalne pripadnosti (Nationalgefühl). ${ }^{156}$ Takva nastojanja mađarska je strana nastojala suzbiti u strahu da će Nijemci prestati biti „prijeko potreban rezervoar za popunjavanje mađarske inteligencije.”157 Iako je postojao sloj „njemački osviještenog seljaštva” (deutschbewusst), nedostajala je „njemački nastrojena inteligencija sposobna za agitaciju" (agitationsfähig), što je predstavljalo veliku prepreku za brzo i uspješno organiziranje njemačkog političkog života u Ugarskoj početkom dvadesetog stoljeća. ${ }^{158} \mathrm{I} \mathrm{u}$ drugom je tekstu prevladavalo mišljenje da se iz povijesti mora izvući pouka i riješiti aktualni problem „nedostatka narodne inteligencije”:

Iz (...) spoznaje da je narod snažan jedino kad ima zdravu inteligenciju (gesunde Intelligenz), postaje jasnije koji je smisao i svrha aktivne brige za narodnost (Volkstumsarbeit) naših akademičara i odgoja njemačkih učenika kao njemački osviještene omladine. ${ }^{159}$

Inteligencija je, dakle, označavala društveni sloj uglavnom visoko obrazovanih ljudi koji su trebali usmjeravati sve važnije društveno-političke promjene.

Spomenuti Toni Mahlberg nije pisao o nedostatku ,inteligencije”, nego se žalio da među njemačkom manjinom ima premalo „intelektualaca” ${ }^{160}$ Stoga se postavlja pitanje tadašnjeg odnosa između ,intelektualca” i ,inteligencije”. Jesu li intelektualci činili inteligenciju, odnosno je li se inteligencija sastojala od intelektualaca? Iako u Student im Volk postoje samo tri mjesta na kojima se spominju „intelektualci”, iz stava Willija Badla može se zaključiti kakva je bila „službena politika” prema njima. Badl se 1939. vratio iz Würzburga s godišnjeg skupa predstavnika njemačkih studenata iz Trećeg Reicha i iz inozemstva (Deutscher Studententag) pun hvale za studente koje je tamo upoznao, zadivljen njihovom spremnošću za djelovanje i za praktičan rad, odnosno time što više ne predstavljaju ,intelektualce koji lebde u uzvišenim prostorima uma" (in höheren geistigen Regionen schwebende Intellektue-

\footnotetext{
156 Matthias HERZOG, „Die deutsche Bewegung im Vorkriegsungarn”, Student im Volk, 1/1939., br. 3, 6.-12. Ovdje 7.

157 Isto.

158 Isto, 9.

159 Fritz HAUG, „Die Mittelschulfrage”, Student im Volk, 1/1939., br. 3, 13.-15. Ovdje 14.

160 T. MAHLBERG, „Berufsplanung”, 5.
} 
lle). ${ }^{161} \mathrm{O}$ Badlovom stavu prema „intelektualnim kružocima” (Intellektuellenzirkel) već je bilo govora.

U svom poimanju „intelektualaca” Badl nije bio nimalo „originalan”. Naprotiv. Pojam „intelektualac" imao je u nacističkom diskursu izrazito negativno značenje. ${ }^{162}$ Bila je to uvreda, ali i optužba kojom se protivnika najteže moglo optužiti. Intelektualci su bili „odnarođene individue”, a intelektualizam „jedna od najvećih opasnosti naših dana” i „smrtni neprijatelj”. ${ }^{163}$ Intelektualcima se, između ostaloga, predbacivalo da im je mišljenje „apstraktno" i „teoretsko”, da im nedostaje snaga, odvažnost i ono najvažnije - „srce” odnosno „karakter”, ${ }^{164}$ a time i izravna veza s narodom iz kojeg potječu. Moglo bi se reći da su bili izvan naroda, a ne $u$ narodu, $\mathrm{u}$ smislu tada propagiranog ideala ostvarivanja neraskidive povezanosti Nijemaca pripadnika svih društvenih slojeva. Kad je Badl nekadašnje studente (Altakademiker) koji se nisu slagali s nacifikacijom nazvao „proizvodom jednog ranijeg liberalnog visokoškolskog odgoja”, ${ }^{165}$ zapravo ih je optužio da su „intelektualci”, u onom pogrdnom nacističkom shvaćanju „beskrvnih” (blutleer), to jest „odnarođenih individua”. ${ }^{166}$ Kao ilustracija službenog nacističkog stava prema intelektualcima može poslužiti izjava samog Hitlera iz studenoga 1938. godine:

Kad promatram intelektualne slojeve kod nas - nažalost, potrebni su; inače bismo ih jednoga dana mogli - ne znam - iskorijeniti ili tako nešto. ${ }^{167}$

Iako je iskoristio pojam „intelektualci”, i Mahlberg je zapravo mislio na „inteligenciju”.

Odgovor na pitanje tko je činio inteligenciju nalazi se i u glasilu Student im Volk, u tekstu u kojem se ona definira kao „stalež umnih radnika” (geistiger Arbeiterstand). ${ }^{168}$ „Umni radnik” je bio član narodne zajednice ravnopravan „radniku šake” (Arbeiter der Faust), svjestan svojih dužnosti prema narodu, kao i svaki drugi stalež. ${ }^{169}$ Pojmove „umni radnik” (Arbeiter der Stirn) i „radnik šake” skovao je Hitler još početkom dvadesetih godina:

Oni se moraju naučiti međusobno cijeniti, umni radnik radnika šake i obrnuto. Nijedan ne postoji bez onoga drugog. Oboje pripadaju zajedno i iz njih dvoje će se iskristalizirati novi čovjek - čovjek nadolazećeg Trećeg Reicha. ${ }^{170}$

Naglasak je, dakle, bio na „radniku”. Za razliku od „odnarođenoga intelektualca”, „umni radnik” (Arbeiter der Stirn odnosno der geistige Arbeiter) je radio na postizanju blagostanja za njemačku narodnu zajednicu - upravo ono što se od studenata zahtijevalo u glasilu Student im Volk.

${ }_{61}$ Willi BADL, „Das Erlebnis von Würzburg”, Student im Volk, 1/1939., br. 3, 15.-16. Ovdje 15. To je direktna, ironična polemika s Karlom Mannheimom.

162 Usp. Dietz BERING, Die Epoche der Intellektuellen. 1898-2001. Geburt, Begriff, Grabmal, Berlin 2010., 85.-129.

163 Isto, 89.-93.

164 Isto, 93.-99.

165 Willi BADL, „Student im Volk”, 2.

166 D. BERING, Die Epoche der Intellektuellen, 103.

167 Isto, 89.

168 Fritz HAUG, „Die Mittelschulfrage”, 13.

169 Isto.

170 Völkischer Beobachter, 5. 6. 1921. Citirano prema: Cornelia SCHMITZ-BERING, Vokabular des Nationalsozialismus, Berlin - New York 2000., 41. 
Analiza tekstova iz Student im Volk pokazuje da negativno konotiranje pojma intelektualac nije značilo istovremeno i protjerivanje znanja i „pameti” iz društva. Naprotiv! Postojala je potreba za obrazovanim ljudima, „radnicima” spremnima i sposobnima da postanu „novi vodeći slojevi, koji će spasiti poniženu domovinu”. ${ }^{171}$ Međutim, da bi se to postiglo, bilo je potrebno stvoriti „novog čovjeka”, prvenstveno čovjeka zajednice, a svako isticanje individualnosti, kao pojma liberalističkog podrijetla, postalo je nepoželjno. Individualni interesi morali su se podrediti interesima zajednice, to jest interesima njemačkog naroda, $u$ skladu s maksimom „dobrobit zajednice ispred vlastite koristi”. ${ }^{172}$

Da bi se stvorio takav vodeći sloj odnosno takva „inteligencija” - pojam koji je, za razliku od „intelektualaca”, imao poželjne konotacije - bila je prema nacističkim shvaćanjima potrebna korjenita promjena odgojno-obrazovnog sustava. Naime, polazeći od stava da je intelektualac proizvod pogrešnog odgoja, ${ }^{173} \mathrm{u}$ kojem se previše pažnje posvećivalo „teoriji” i „apstrakciji”, nakon dolaska nacista na vlast sve češće se doslovno blatilo tradicionalno intelektualno formiranje i tradicija njemačkog Bildungsbürgertum, u korist izgradnje nacističkog svjetonazora (Gesinnung) i „tjelesnog jačanja”, ${ }^{174}$ uz opravdanje da se živi u „vremenima u kojima ne odlučuje samo duh, nego i šaka". ${ }^{175}$ Samo su oni koji su prošli novi sustav obrazovanja, mogli postati novi vodeći sloj Nijemaca, koji će svoje znanje iskoristiti za napredak čitavog njemačkog naroda.

Da bi se pak spriječilo nepoželjno nastajanje „intelektualaca”, djecu je već od najranijeg djetinjstva bilo potrebno pripremati za njihove buduće dužnosti jer se smatralo da upravo o mladeži ovisi budućnost njemačkog naroda. ${ }^{176}$ Osim obrazovanju djece posebna pažnja se zato poklanjala i obrazovanju studenata jer su upravo oni - u vremenima kad je fakultetsko obrazovanje bilo dostupno tek malom broju ljudi - bili predodređeni da formiraju krug nove „inteligencije”.

U tom kontekstu treba istraživati i glasilo Student im Volk.

\footnotetext{
171 Isto, 91.

172 Anne C. NAGEL, Hitlers Bildugsreformer. Das Reichsministerium für Wissenschaft, Erziehung und Volksbildung 19341945, Frankfurt am Main 2012., 150.

173 D. BERING, Die Epoche der Intellektuellen, 105

174 Rudolf VIERHAUS, „Bildung”, Geschichtliche Grundbegrife, sv. 1, Stuttgart 1992., 508.-551. Ovdje 550.

175 D. BERING, Die Epoche der Intellektuellen, 106.

176 Usp. primjerice zakon o Hitlerovoj mladeži (Hitlerjugend) iz prosinca 1936. Dokument je dostupan na http://www. dhm.de/lemo/html/dokumente/hjgesetz (16. 2. 2013.).
} 


\section{$\cos$}

\section{STUDENT IM VOLK: “ThOSE WHO ARE NOT WITH US ARE AGAINST US!"}

In March 1939, the first issue of Student im Volk, a magazine for German students in Yugoslavia, was published by the German Students Society of Zagreb. The magazine did not just publish articles about "typical student themes", but instead it dealt with such subject matter as the lives of peasants, the war, history, politics, secondary education, etc. Normative texts took up a great part of the magazine, in which students were given advice on how to achieve the imaginary ideal of becoming an active member of the nation, with an ingrained sense of duty. The duty towards one's own people was deemed to be the most important: German students were supposed to value the laws of blood, land and honour above personal interest. No German was allowed to fail in their role, or in the words of the magazine's owner, Landesstudentenführer Willi Badl: "Those who are not with us are against us!" Immediately upon the publication of the magazine's first issue, the government started monitoring its contents, as well as the activities of the society's members, under suspicion of spreading Nazi propaganda. The activities of Willi Badl and Richard Stieb, the magazine's editor in chief were under particular scrutiny.

The paper analyzes texts published in the magazine (1939-1940) and investigates its role in the mobilization of the students. It also attempts to discern which characteristics were expected of the German student, as well as wether they were allowed to become "intellectuals". It also presents the transformation of the German Students Society in Zagreb from an association originally intended to facilitate socialization among Zagreb's students of German nationality to an organ of Nazi propaganda.

Keywords: students, Nazism, Germans in Yugoslavia, intellectuals, intelligentsia, Germans students society in Zagreb, mobilization, Student im Volk, Willi Badl

\section{$\cos$}

\section{Izvori i literatura}

\section{Neobjavljeni izvori}

Pravila Udruženja nemačkih studenata u Zagrebu, Hrvatski državni arhiv, Zagreb (dalje: HDA), 1353: grupa VI, kut. 24, inv. br. 2350.

HDA, Zagreb, 1358: grupa XI, Zbirka špijunaža i peta kolona, kut. 29, inv. br. 2774, 2776, 2779, 2877, 2881; kut. 32, inv. br. 2903, 2904.

\section{Objavljeni izvori}

Cillier Zeitung (Celje), br. 80, 13. 10. 1927.

Deutsche Nachrichten (Zagreb), 1939.

Die Bewegung: Zeitung der deutschen Studenten (München), 1943.-1944.

Morgenblatt (Zagreb), 1928.

Student im Volk (Zagreb), 1939.-1940. 


\section{Literatura}

Vladimir ANIĆ, Rječnik hrvatskoga jezika, Zagreb 2000.

Alaida ASMAN, Duga senka prošlosti, Beograd 2011.

Jovan BAJFORD, Staro sajmište. Mesto sećanja, zaborava i sporenja, Beograd 2011.

Nikica BARIĆ, „Njemačka manjina u dokumentima banskih vlasti Banovine Hrvatske, 1939. 1941.", Časopis za suvremenu povijest, 34/2002., br. 2, 435.-470.

Dietz BERING, Die Epoche der Intellektuellen. 1898-2001. Geburt, Begriff, Grabmal, Berlin 2010.

Carl BETHKE, Deutsche und ungarische Minderheiten in Kroatien und der Vojvodina 1918-1941. Identitätsentwürfe und ethnopolitische Mobilisierung, Wiesbaden 2009.

Goran BEUS RICHEMBERGH, Nijemci, Austrijanci i Hrvati I. Prilozi za povijest njemačko-austrijske nacionalne manjine u Hrvatskoj i Bosni i Hercegovini, Zagreb - Sarajevo - Osijek 2010.

Dušan BIBER, Nacizem in Nemci v Jugoslaviji, Ljubljana 1966.

Anette BLASCHKE, „Ideologische Mobilisierung im “völkischen Kernland”, Workshop „Mobilisierung im Nationalsozialismus”, Jena, 10./11. März 2010. (http://www1.uni-jena.de/ns-gaue/ workshop_2010.htm)

Werner CONZE, „Bauer. Bauernstand, Bauerntum”, Geschichtliche Grundbegrife, sv. 1, Stuttgart 1992., 407.-439.

Duden. Deutsches Universalwörterbuch, Mannheim - Leipzig - Wien - Zürich 2003.

Enciklopedija Jugoslavije, sv. 5, Jugos-Mak, Zagreb 1962.

Milton J. ESMAN, Ethnic politics, New York 1994.

Mitja FERENC - Božo REPE, „Nemška manjšina v Sloveniji med obema vojnama”, Slovenskoavstrijski odnosi v 20 stoletju. Slowenisch - österreichische Beziehungen im 20. Jahrhundert, (ur. Dušan Nećak i dr.), Ljubljana 2004., 147.-160.

Ranka P. GAŠIĆ, „Nemački kulturni uticaj u Beogradu tridesetih godina 20. veka”, Istorija 20. veka, 21/2003., br. 1, 31.-46.

Vladimir GEIGER, Nijemci Đakova i Đakovštini od 1848. do 1914. godine, sv. 1 i sv. 2, Zagreb 2001. i 2002.

Vladimir GEIGER, Nijemci u Đakovu i Đakovštini, Zagreb 2001.

Vladimir GEIGER, „Njemačka manjina u Kraljevini Srba, Hrvata i Slovenaca / Jugoslaviji (1918. - 1941.)", Dijalog povjesničara - istoričara, 2, (ur. Hans-Georg Fleck i Igor Graovac), Zagreb 2000., 429.-445.

Vladimir GEIGER, „Položaj njemačke manjine u bivšoj Jugoslaviji (s posebnim osvrtom na razdoblje nakon drugog svjetskog rata)", Historijski zbornik, 46/1993., br. 1, 165.-175.

Ivo GOLDSTEIN, Hrvatska povijest, Zagreb 2008.

Ivo GOLDSTEIN, Židovi u Zagrebu 1918-1941., Zagreb 2004.

Rüdiger HACHTMANN, „Netzwerke und Selbstmobilisierung, Eliten und Neue Staatlichkeit - Thesen zur Binnenstruktur der NS-Herrschaft”, Workshop „Mobilisierung im Nationalsozialismus", Jena, 10./11. März 2010. (http://wwwl.uni-jena.de/ns-gaue/workshop_2010.htm)

Zoran JANJETOVIĆ, Deca careva, pastorčad kraljeva. Nacionalne manjine u Jugoslaviji 1918-1941, Beograd 2005.

Zoran JANJETOVIĆ, Nemci u Vojvodini, Beograd 2009.

Tomislav JONJIĆ, „Proces Hranilović-Soldin. Prilog poznavanju postanka ustaškog pokreta”, $\mathrm{Hr}$ vatska između slobode i jugoslavenstva: zbornik radova sa znanstvenog skupa održanog 8. i 9. siječnja 2009. u Zagrebu, (ur. Tomislav Jonjić i Trpimir Matijević), Zagreb 2009., 167.-196. 
Mira KOLAR-DIMITRIJEVIĆ, „Doprinos Nijemaca i Austrijanaca obrtništvu Zagreba do 1945. godine", Povijesne zaobilaznice: Nijemci i Austrijanci u Hrvatskoj, (ur. Nives Rittig Beljak i Ljiljana Marks), Zagreb 2009., 12.-64.

Mira KOLAR-DIMITRIJEVIĆ, Skrivene biografije nekih Nijemaca i Austrijanaca u Hrvatskoj 19. i 20. stoljeća, Osijek 2001.

Reinhart KOSELLECK, „Volk', 'Nation', 'Nationalismus' und 'Masse' 1914 - 1945”, Geschichtliche Grundbegriffe, sv. 7, Stuttgart 1992., 389.-439.

Mijo MIRKOVIĆ, Ekonomska historija Jugoslavije, Zagreb 1968.

Josef MÜLLER, „O djelovanju njemačkih visokoškolaca u Zagrebu (Sjećanje na osnutak VDH Zagreb i Suevia - Beograd)", Povijesne zaobilaznice: Nijemci i Austrijanci u Hrvatskoj, (ur. Nives Rittig Beljak i Ljiljana Marks), Zagreb 2009., 199.-211.

Josef MÜLLER-INDIA, VDH-Agram, Suevia-Belgrad: 40 Jahre, Salzburg 1964.

Anne C. NAGEL, Hitlers Bildugsreformer. Das Reichsministerium für Wissenschaft, Erziehung und Volksbildung 1934-1945, Frankfurt am Main 2012.

Branko PETRANOVIĆ, Istorija Jugoslavije 1918 - 1988. Knjiga prva, Beograd 1980.

Božo REPE, „Intelektualci, političke stranke i grupacije u Sloveniji u predvečerje Drugog svetskog rata", Intelektualci i rat 1937.-1947. Zbornik radova s mecunarodnog skupa Desničini susreti 2012. (u tisku)

Cornelia SCHMITZ-BERING, Vokabular des Nationalsozialismus, Berlin - New York 2000.

Arnold SUPPAN, Jugoslawien und Österreich 1918-1938. Außenpolitik im europäischen Umfeld, Wien - München 1996.

Rudolf VIERHAUS, „Bildung”, Geschichtliche Grundbegrife, sv. 1, Stuttgart 1992., 508.-551.

Michael WEDEKIND, „Znanost i politika. Restrukturiranje Slovenije, 1939.-1945.”, Intelektualci $i$ rat 1937.-1947. Zbornik radova s međunarodnog skupa Desničini susreti 2011., (ur. Drago Roksandić i Ivana Cvijović Javorina), Zagreb 2012., 83.-96.

Arndt WEINRICH, Der Weltkrieg als Erzieher. Jugend zwischen Weimarer Republik und Nationalsozialismus, Essen 2012.

Holger ZINN, Das studentische Kameradschaftswesen im Dritten Reich unter besonderer Berücksichtigung der Bünde von DL und VC, Würzburg 2001.

Friedrich ZUNKEL, „Ehre, Reputation”, Geschichtliche Grundbegriffe, sv. 2, Stuttgart 1992., 1.-63. 